\title{
最近の新しいモノマー
}

\section{岩倉義 男*}

New Monomers.

Yoshio IWAKURA*

\section{I.はじめに}

本特集に㧍いては高分子製造原料として多量に使用さ れているビニルモノマーについて, 重合反応以外の化学 反応に如何に利用されているかを主体にして企画されて いる。その意味で新しいモノマーをとらえて執筆するの がより忠実な態度とも思ったが，筆者はむしろその考え 方を従にしてどのような新しいモノマーがどのような目 的のために合成されているかの考え方を主体にして執筆 することにした。モノマーは主として頁数の都合でビニ ルモノマーの解説になったが他のノンビニルモノマーに ももっと触れるべきであったし, さらにまたほとんど触 机得ずに終った重縮合, 重付加反応に用いられる新しい 原料モノマーについても解説すべきだったであろう。

ここ仅りあげたモノマーは数多くある新しいモノマ 一の中からここ数年間報告されたものを主体として抽出 したものであり, 特に筆者の研究室で研究したものと筆 者の日頃興味を持っていたモノマーについてと二大別し てトピックス的に紹介することにした。したがって重要 なものの取りこぼしもあろらかと思らがその点諒承を願 うことにしたい。

なおここにあげたビニルモノマーについて重合反応以 外の化学反応性は, 本誌で特集された他のビニルモノマ 一の反応性などから類推して大いに注目されるべきもの も多かららと思うわけで, その今後の発展に期待して行 きたいと思う。

\section{II. 各諭}

1. アクリロイルおよびメタクリロイル $\alpha-$ アミノ酸

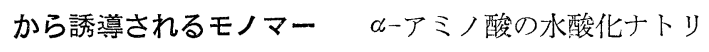

* 東京大学工学部合成化学教室

* Faculty of Engineering, University of Tokyo
ウム水溶液にアクリロイルまたはメタクリロイルクロリ ドを 0 1 $10^{\circ} \mathrm{C}$ で添加すると Schotten Baumann 反応がお きて相当するアクリロイルきたはメタクリロイル $\alpha-ア ~$ ミノ酸が生成する。永またはベンゾールから再結晶す る。結果 ${ }^{1}$ 表 1 亿示す。

$\mathrm{R}_{2} \quad \mathrm{R}_{1}$

$\mathrm{CH}_{2}=\stackrel{!}{\mathrm{C}}-\mathrm{CCl}+\mathrm{H}_{2} \mathrm{~N}-\stackrel{\mathrm{C}}{\mathrm{C}} \mathrm{HCOONa}$ $\mathrm{O}$

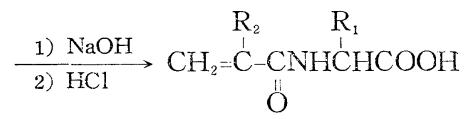

表 1 N-アクリロイルおよびメタクリロイルー $\alpha-$ アミノ酸

\begin{tabular}{l|l|c|c}
\hline \multicolumn{1}{c|}{$\mathrm{R}_{1}$} & $\mathrm{R}_{2}$ & 收率 $(\%)$ & $\mathrm{mp}\left({ }^{\circ} \mathrm{C}\right)$ \\
\hline $\mathrm{CH}_{3}$ & $\mathrm{H}$ & 65 & 130 \\
$\mathrm{CH}_{3}$ & $\mathrm{CH}_{3}$ & 70 & $118^{2)}$ \\
$\left(\mathrm{CH}_{3}\right)_{2} \mathrm{CHCH}_{2}$ & $\mathrm{H}$ & 90 & 82 \\
$\left(\mathrm{CH}_{3}\right)_{2} \mathrm{CHCH}_{2}$ & $\mathrm{CH}_{3}$ & 90 & 106 \\
$\mathrm{C}_{6} \mathrm{H}_{5} \mathrm{CH}_{2}$ & $\mathrm{H}$ & 75 & 119 \\
$\mathrm{C}_{6} \mathrm{H}_{5} \mathrm{CH}_{2}$ & $\mathrm{CH}_{3}$ & 80 & 104 \\
$\left(\mathrm{CH}_{3}\right)_{2} \mathrm{CH}$ & $\mathrm{CH}_{3}$ & 75 & $102^{3)}$ \\
\hline
\end{tabular}

i. 2-イソプロペニル-4-アルキル-4-アセチル-2-オキ

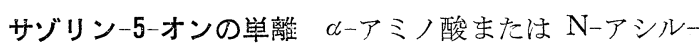
ムーアミノ酸をピリジン中で酸無水物と反応させると $\mathrm{N}$ -

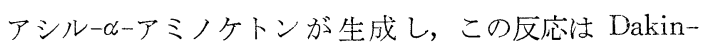
West 反応と呼ばれる。Dakin-West 反応においては中 聞に4-アセチルオキサゾロンの生成が考えられていた が従来単離されていなかった。N-メタクリロイルームーア ミノ酸のピリジン溶液に過剩の無水䣷酸を添加し, $10^{\circ} \mathrm{C}$ 以下で反応させると，Dakin-West 反応の中間生成物 4-アセチル-5-オキサゾロンが減圧蒸留により純粋な形 で単離された。

反応式は次の通りであり, 結果を表 2 に示す。

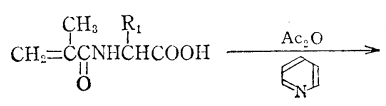




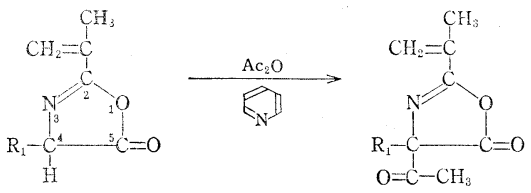

表 2 2-イソプロペニル-4-アセチル-5-オキ サゾロン化合物

\begin{tabular}{l|c|c}
\hline \multicolumn{1}{c|}{$\mathrm{R}_{1}$} & 收 率 $(\%)$ & $\mathrm{bp}\left({ }^{\circ} \mathrm{C}\right)(\mathrm{mm} \mathrm{Hg})$ \\
\hline $\mathrm{CH}_{8}$ & 80 & $79(0.15)$ \\
$\left(\mathrm{CH}_{3}\right)_{2} \mathrm{CHCH}_{2}$ & 76 & $92(1)$ \\
$\mathrm{C}_{6} \mathrm{H}_{5} \mathrm{CH}_{2}$ & 78 & $130(1)$ \\
\hline
\end{tabular}

ii. N-アクリロイルおよび $\mathrm{N}-$ メタクリロイル- $\boldsymbol{a}-\boldsymbol{3}$

ミノケトンの合成 2-イソプロペニル-4-アセチル-5-才 キサゾロンを酢酸ーピリジン中で加熱すると Dakin-West 反応が進行して $\mathrm{N}$-メタクリロイルー片アミノケトンが 生成する。 $\mathrm{N}$-アクリロイルまたは $\mathrm{N}$ ーメタクリロイルー のーアミノ酸定ピリジンの存在下過剩の無水酶酸と反応さ せ，最後に $100^{\circ} \mathrm{C}$ に加熱すると脱炭酸反忘が進行し，相 当する N-アクリロイルまたは N-メタクリロイルミノケトンが生成する。これらは隇圧蒸留または再結晶 により精製される。結果 ${ }^{4}$ は表 3 亿 A 法として示す。

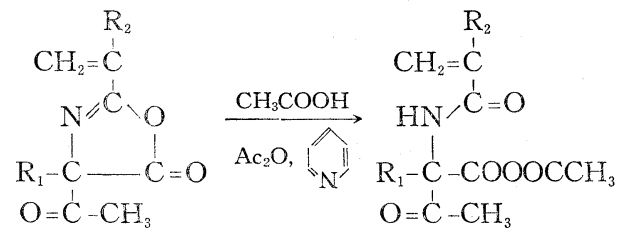

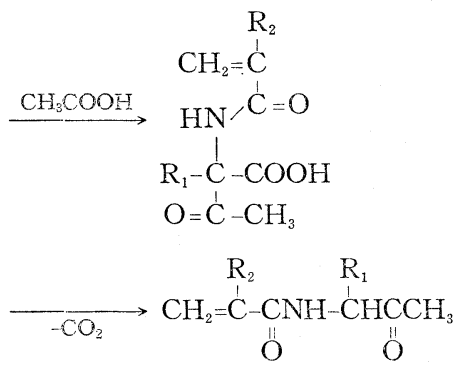

これらアミノケトン体は相当する 酸塩とアクリル酸クロリドまたはメタクリル酸クロリド とから Schotten-Baumann の反応でも合成される。結 果 ${ }^{4)}$ は表 3 亿 B 法として示す。

$$
\begin{aligned}
& \mathrm{R}_{2} \quad \mathrm{R}_{1} \\
& \mathrm{CH}_{2}=\mathrm{C} \mathrm{COCl}+\mathrm{H}_{2} \mathrm{~N}-\mathrm{CHCOCH}_{3} \\
& \mathrm{R}_{2} \quad \mathrm{R}_{1} \\
& \stackrel{\mathrm{Na}_{2} \mathrm{CO}_{3}}{\longrightarrow} \mathrm{CH}_{2}=\mathrm{C}-\mathrm{CONHCHCOCH}
\end{aligned}
$$

表 $3 \mathrm{~N}-[1$-(1-置換-2-オキソプロピル)]-ア シルアミド

\begin{tabular}{l|l|rc|r|r}
\hline \multicolumn{1}{c|}{$\mathrm{R}_{\mathbf{1}}$} & $\mathrm{R}_{\mathbf{2}}$ & \multicolumn{2}{|c|}{ 收率 } \\
A 法 & B法 & $\left({ }^{\circ} \mathrm{C}\right)(\mathrm{mmHg})$ & \multicolumn{1}{c|}{$\mathrm{mp}$} \\
& & $\left.{ }^{\circ} \mathrm{C}\right)$ \\
\hline $\mathrm{H}$ & $\mathrm{H}$ & 0 & 20 & $110(1)$ & - \\
$\mathrm{H}$ & $\mathrm{CH}_{3}$ & 0 & 18 & $110(2)$ & - \\
$\mathrm{CH}_{3}$ & $\mathrm{H}$ & 62 & 45 & $115(4)$ & 64 \\
$\mathrm{CH}_{3}$ & $\mathrm{CH}_{3}$ & 78 & 55 & $95(2)$ & 35 \\
$\left(\mathrm{CH}_{3}\right)_{2} \mathrm{CHCH}_{2}$ & $\mathrm{H}$ & 65 & - & $137(2)$ & 45 \\
$\left(\mathrm{CH}_{3}\right)_{2} \mathrm{CHCH}_{2}$ & $\mathrm{CH}_{3}$ & 72 & - & $121(2)$ & 43 \\
$\mathrm{C}_{6} \mathrm{H}_{5} \mathrm{CH}_{2}$ & $\mathrm{H}$ & 60 & 75 & - & 132 \\
$\mathrm{C}_{6} \mathrm{H}_{5} \mathrm{CH}_{2}$ & $\mathrm{CH}_{3}$ & 90 & 80 & - & 92 \\
\end{tabular}

iii. 2-ビニル およびイソプロペニルオキサン゙ールの 合成 N-アクリロイルまたは $\mathrm{N}-$ メタクリロイル- 6 -ア ミノクトンを $116 \%$ ポリリン酸 (PPA) 中で $140^{\circ} \mathrm{C}$ で反 応させると脱水閉環してオキサゾールを生成する。生成 物以減圧蒸留で精製する。結果 ${ }^{4}$ は表 4 亿示す。

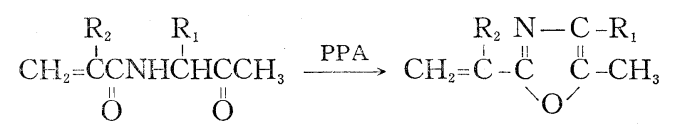

表 4 2-ビニルおよび 2-イソプロペニルオキサゾール

\begin{tabular}{l|l|r|r|c}
\hline \multicolumn{1}{c|}{$\mathrm{R}_{1}$} & \multicolumn{1}{c|}{$\mathrm{R}_{2}$} & $\begin{array}{c}\text { 収 } \\
(\%)\end{array}$ & $\begin{array}{c}\text { bp } \\
\left({ }^{\circ} \mathrm{C}\right)(\mathrm{mmHg})\end{array}$ & $n_{\mathrm{D}}^{20}$ \\
\hline $\mathrm{H}$ & $\mathrm{CH}_{3}$ & 60 & $50(10)$ & 1.4877 \\
$\mathrm{CH}_{3}$ & $\mathrm{H}$ & 60 & $61(20)$ & 1.4875 \\
$\mathrm{CH}_{3}$ & $\mathrm{CH}_{3}$ & 80 & $77(25)$ & 1.4889 \\
$\left(\mathrm{CH}_{3}\right)_{2} \mathrm{CHCH}_{2}$ & $\mathrm{H}$ & 50 & $83(15)$ & 1.4825 \\
$\left(\mathrm{CH}_{3}\right)_{2} \mathrm{CHCH}_{2}$ & $\mathrm{CH}_{3}$ & 55 & $85(10)$ & 1.4811 \\
$\mathrm{C}_{6} \mathrm{H}_{5} \mathrm{CH}_{2}$ & $\mathrm{H}$ & 30 & $115(4)$ & 1.5653 \\
$\mathrm{C}_{6} \mathrm{H}_{5} \mathrm{CH}_{2}$ & $\mathrm{CH}_{3}$ & 40 & $120(2)$ & 1.5548 \\
\hline
\end{tabular}

iv. 2-イソプロペニル-4, 5-ジメチルチアゾールの合 成 N-(1-メチル-2-オキyプロピル)-メタクリロイル アミドを $100^{\circ} \mathrm{C}$ で五硫化リンと反応させる。生成物は減 圧蒸留で精製する。収率 $50 \%$, 沸点 $85^{\circ} \mathrm{C}(5 \mathrm{mmHg})$, $n_{\mathrm{D}}^{20} 1.5417^{4)}$ 。

$$
\begin{aligned}
& \mathrm{CH}_{3} \quad \mathrm{CH}_{3} \\
& \mathrm{CH}_{2}=\stackrel{\mathrm{C}}{\mathrm{C}}-\mathrm{CNH}-\mathrm{C} \mathrm{C}-\mathrm{CCH}_{3} \\
& \stackrel{\mathrm{O}}{\mathrm{O}} \\
& \stackrel{\mathrm{P}_{2} \mathrm{~S}_{5}}{\longrightarrow} \mathrm{CH}_{2}=\stackrel{\mathrm{C}}{\mathrm{C}}-\mathrm{I}_{\mathrm{S}^{\prime}}^{\mathrm{C}} \stackrel{\mathrm{C}}{\mathrm{C}}-\mathrm{CH}_{3}
\end{aligned}
$$

v. 2-ビニルおよび 2-イソプロペニル-5-オキサゾロ ンの合成 $\mathrm{N}$-アクリロイルおよび $\mathrm{N}$-メタクリロイル-

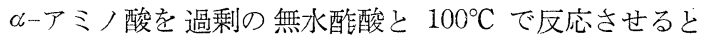
脱水閉環して 2-ビニルおよび 2-イソプロペニル $-5-オ$ キサゾロンを生成する。 


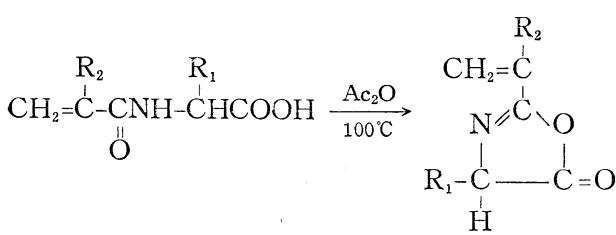

$\mathrm{R}_{1}:\left(\mathrm{CH}_{3}\right)_{2} \mathrm{CH},\left(\mathrm{CH}_{3}\right)_{2} \mathrm{CHCH}_{2}$ $\mathrm{R}_{2}: \mathrm{H}, \mathrm{CH}_{3}$

このモノマーは 4 位の水素が活性水素であるため， ラ ジカル重合では連鎖移動をおこし易くなり，重合体の重 合度は上昇しない。またこのモノマーは後述するように 塩基の存在で加熱すると容易にプソイドオキサゾロンに 異性化する。

次に 2-イソプロペニル-4-イソプロピル-2-オキサゾ リン-5-オンの 合成例を示す。 $100^{\circ} \mathrm{C}$ に加熱された 無水 酢酸中にできるだけ迅速に N-メタクリロイル-D, L-バ リンを添加し， $100^{\circ} \mathrm{C}$ でさらに 5 分間反応させる。生成 物は減圧蒸留で精製 する ${ }^{5)}$ 。収率 $51 \%$, bp $100 \sim 103^{\circ} \mathrm{C}$ (20 mm Hg)， $n_{\mathrm{D}}^{20} 1.4641$ 。

同様にして 2-イソプロペニル-4-イソブチル-5-オキ サゾロンが合成される。収率 $50 \%$, bp $70^{\circ} \mathrm{C}(2 \mathrm{mmHg})$

なお 2-ビニル-4-イソプロピルー5-オキサゾロンは収 率 $20 \%$ で合成される。bp $53 \sim 55^{\circ} \mathrm{C}(3 \mathrm{mmHg})$ 。

4 位の 活性水素を 全部アルキル置換した 2-イソプロ ペニル-4, 4-ジアルキル-5-オキサゾロンは予期したよう に安定で，ラジカル重合により高分子量の重合体を与え る。一連のジアルキルモノマーは，まず相当するケトン とシアン化カリウム, 炭酸アンモニウムとの反応でヒダ ントインをつくり，ついでこれからの相当する

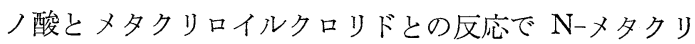
ロイル $\alpha$ ーアミノ酸とし，これを過剩の無水酢酸と 100 $\sim 110^{\circ} \mathrm{C}$ に加熱し閉環させて合成する。

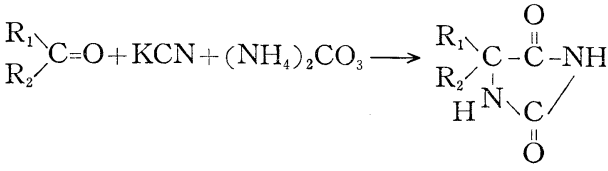

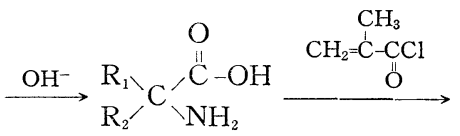<smiles>[R4]C1([R2])N=C(OC(=O)C([R])([R])NC(=O)C(=C)C)OC1=O</smiles>

結果を表 5, 表 6 に示す。

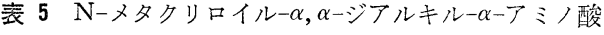

\begin{tabular}{rc|c|c}
\hline $\mathrm{R}_{1}$ & $\mathrm{R}_{2}$ & 収 率 $(\%)$ & \multicolumn{1}{c}{$\mathrm{mp}\left({ }^{\circ} \mathrm{C}\right)$} \\
\hline $\mathrm{CH}_{3}$ & $\mathrm{CH}_{3}$ & 37 & $159 \sim 160$ \\
$\mathrm{CH}_{3}$ & $\mathrm{CH}_{3} \mathrm{CH}_{2}$ & 25 & $88 \sim 90$ \\
$\mathrm{CH}_{3}$ & $\left(\mathrm{CH}_{3}\right)_{2} \mathrm{CHCH}_{2-}$ & 53 & $87 \sim 89$ \\
& $\left(\mathrm{CH}_{2}\right)_{5}$ & 53 & $177 \sim 178$ \\
\hline
\end{tabular}

亚 6 2-イソプロペニル-4, 4-ジアルキル-5-オキサゾロン

\begin{tabular}{rc|c|c|c}
\hline $\mathrm{R}_{1}$ & $\mathrm{R}_{2}$ & 收率(\%) & ${ }^{\circ} \mathrm{C}(\mathrm{mp} \mathrm{mHg})$ & $\mathrm{mp}\left({ }^{\circ} \mathrm{C}\right)$ \\
\hline $\mathrm{CH}_{3}$ & $\mathrm{CH}_{3}$ & 56 & $75 \sim 76(19)$ & - \\
$\mathrm{CH}_{3}$ & $\mathrm{CH}_{3} \mathrm{CH}_{2}$ & 51 & $68 \sim 70(8)$ & - \\
$\mathrm{CH}_{3}$ & $\left(\mathrm{CH}_{3}\right)_{2} \mathrm{CHCH}_{2}-$ & 64 & $75 \sim 76(5)$ & - \\
& $\left(\mathrm{CH}_{2}\right)_{5}$ & 74 & $118 \sim 120(5)$ & $52 \sim 54$ \\
\hline
\end{tabular}

これらのイソプロペニルジアルキルオキサゾロン $\left(\mathrm{M}_{2}\right)$ はスチレン $\left(\mathrm{M}_{1}\right)$ やメタクリル酸メチルと共重合 させることができる。モノマー反応性比を衰 7 に示す が，5-オキサゾロン環は二重結合に対し電子吸引性に作 用している。

表 7 モノマー反応性比 $\left(60^{\circ} \mathrm{C}\right)$

\begin{tabular}{cc|c|c}
\hline $\mathrm{R}_{1}$ & $\mathrm{R}_{2}$ & $r_{1}$ & $r_{2}$ \\
\hline $\mathrm{CH}_{3}$ & $\mathrm{CH}_{3}$ & 0.31 & 1.00 \\
$\mathrm{CH}_{3}$ & $\mathrm{CH}_{3} \mathrm{CH}_{2}$ & 0.27 & 0.70 \\
$\mathrm{CH}_{3}$ & $\left(\mathrm{CH}_{3}\right)_{2} \mathrm{CHCH}_{2}-$ & 0.24 & 0.69 \\
& $\left(\mathrm{CH}_{2}\right)_{5}$ & 0.12 & 0.82 \\
$\mathrm{H}$ & $\left(\mathrm{CH}_{3}\right)_{2} \mathrm{CH}$ & 0.31 & 1.12 \\
\hline
\end{tabular}

共重合体中の側鎖のオキサゾロン環はたとえばアミン と開環付加反応を行なら ${ }^{6)}$ 。

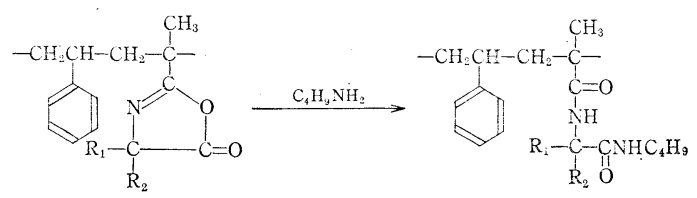

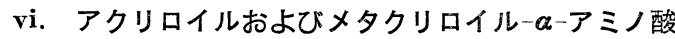

アミド $\alpha$ アミノ酸エチルエステルとアンモニアとから 生成した クリロイルクロリドとをヒドロキノンの存在で縮合させ ると標記のモノマーが生成する ${ }^{7} 。$

$$
\begin{aligned}
& \mathrm{R}_{1} \quad \mathrm{R}_{2} \\
& \mathrm{H}_{2} \mathrm{~N}-\mathrm{CHCONH} \mathrm{H}_{2}+\mathrm{CH}_{2}=\mathrm{C}-\mathrm{COCl} \\
& \mathrm{R}_{2} \quad \mathrm{R}_{1} \\
& \longrightarrow \mathrm{CH}_{2}=\stackrel{\mathrm{C} C O N H C H C O N H}{ } \\
& \mathrm{R}_{2}: \mathrm{H}, \mathrm{CH}_{3} \mathrm{R}_{1}: \mathrm{H}, \mathrm{CH}_{3}
\end{aligned}
$$

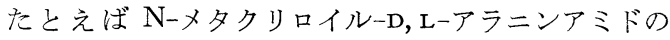
収率は $90 \%$ で融点は $147^{\circ} \mathrm{C}$ である。

$\mathrm{N}$-メタクリロイルグリシンアミドなどいわゆるビニ 
ルペプチドは次式のようにイソプロペニルオキサゾロン Łアンモニアとの反応でも合成される

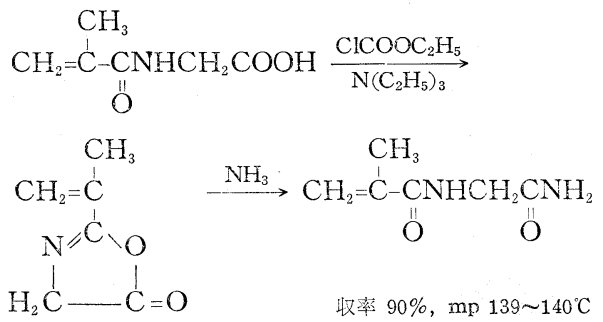

この種のビニルペプチドからの重合体は水中でゼラチ ンに似た熱可逆的なゲルを生成する。

vii. アルキリデンプソイドオキサン゙ロンの合成 Nアクリロイルおよびメタクリロイルー枋アミノ酸芫ピリ ジン中当量の無水酢酸とと日に $100^{\circ} \mathrm{C}$ で反応させると 2-イソプロピリデン-3-オキサゾリン-5-オンすなわちア ルキリデンプソイドオキサゾロンが生成する。前述した ようにこの化合物はビニルまた注イソプロペニルオキサ ゾロン (1) をピリジンとともに加熱しても異性化して合 成されるので，その生成機構は次のように考えられる。
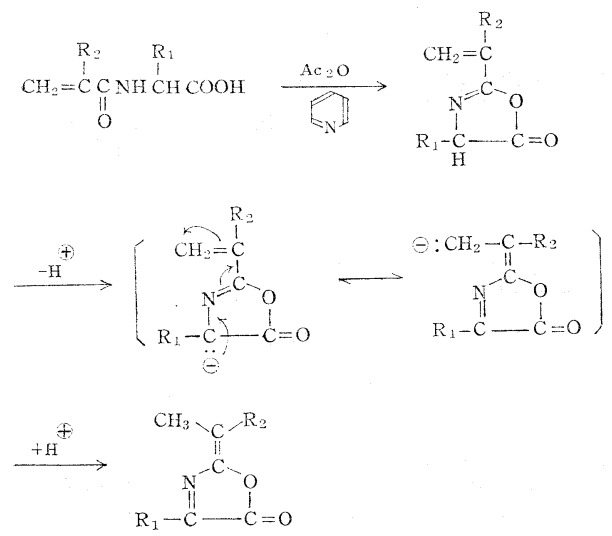

(1)

結果 ${ }^{9)}$ 表 8 に示す。

表 8 アルキリデソプソイドオキサゾロン

\begin{tabular}{cc|c|c|c}
\hline $\mathrm{R}_{1}$ & $\mathrm{R}_{2}$ & ${ }^{\circ} \mathrm{C}(\mathrm{mpmHg})$ & $(\%)$ & $n_{\mathrm{D}}^{20}$ \\
\hline $\mathrm{CH}_{3}$ & $\mathrm{CH}_{3}$ & $54 \sim 56(1.5)$ & 41 & 1.5437 \\
$\mathrm{CH}_{3}$ & $\left(\mathrm{CH}_{3}\right)_{2} \mathrm{CH}$ & $74 \sim 76(1)$ & 64 & 1.5191 \\
$\mathrm{CH}_{3}$ & $\left(\mathrm{CH}_{3}\right)_{2} \mathrm{CHCH}_{2}$ & $84 \sim 86(1)$ & 78 & 1.5159 \\
$\mathrm{CH}_{3}$ & $\left(\mathrm{CH}_{3}\right)_{3} \mathrm{C}$ & $73 \sim 74(1)$ & 69 & 1.5051 \\
$\mathrm{CH}_{3}\left(\mathrm{CH}_{2}\right)_{3}$ & $\left(\mathrm{CH}_{3}\right)_{2} \mathrm{CH}$ & $86 \sim 88(0.7)$ & 58 & 1.5036 \\
\hline
\end{tabular}

プソイドオキサゾロンは興味ある化学反応を行なうこ とが見出されている。希アルカリ水溶液で加水分解する と次例のような生成物を与える。

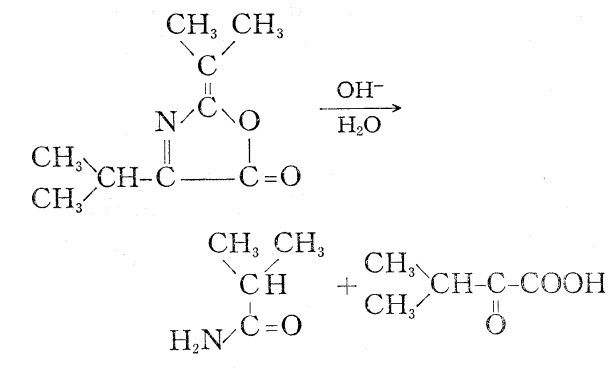

イソプロピリデンプソイドオキサゾロンは 2 モルのア ニリンとの反応で 1,4-付加と開環付加を行なった生成 物定与える ${ }^{101}$ 。

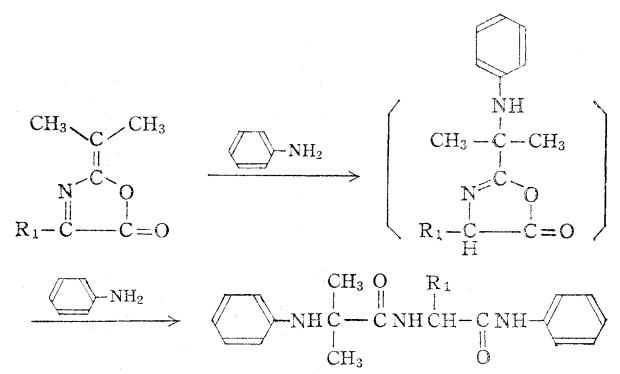

イソプロピリデンプソイドオキサゾロンとメルカプタ ンとをトリエチルアミンの存在で反応させるとアミンの 場合と同じく 1,4-付加と開環付加による 1:2 付加体を 与える。この反応は重付加反応に利用できる ${ }^{11} 。$

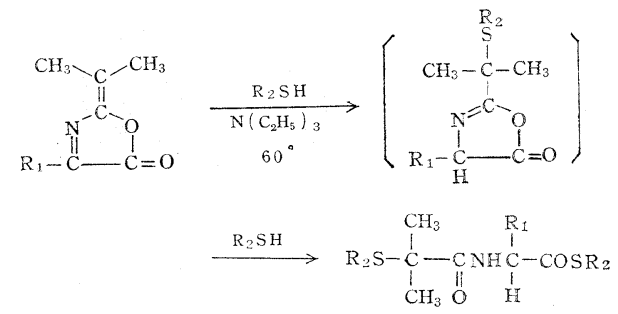

たとえば 2-イソプロピリデンー4-メチル-3-オキサゾ リン-5-オンとチオフェノールとの反応では $97 \%$ 収率で 融点 $64 \sim 66^{\circ} \mathrm{C}$ の $1: 2$ 付加体が得ら机る。

イソプロピリデンプソイドオキサゾロン (1) とベンゾ ールとのフリーデルクラフッ反応でも $1: 2$ 付加体を生 成する ${ }^{12)}$ 。

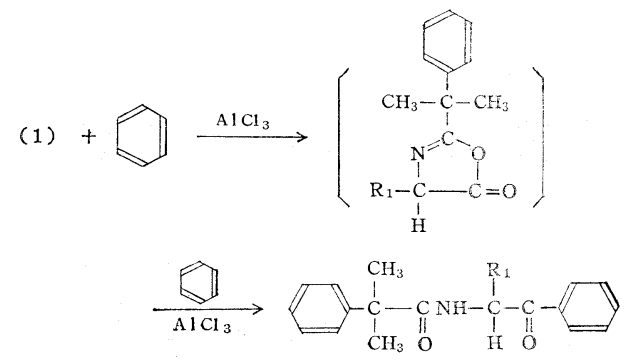


（1）とグリニャ一試薬とは中間に異性化反応を伴なっ たと考えられる生成物ピロリジンジオンを与える ${ }^{13)} 。$

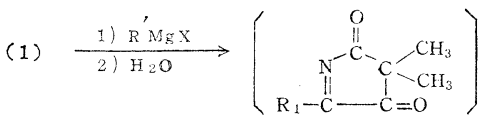<smiles>[R]C1([R])NC(=O)C(C)(C)C1=O</smiles>

（1）と有機りチウム化合物との反忘も同様な異性化を 伴ならが，生成物泣前と異なり，4-ヒドロキシー2-ピロ リジノンである ${ }^{13)}$

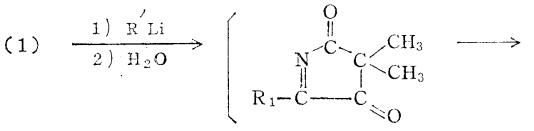

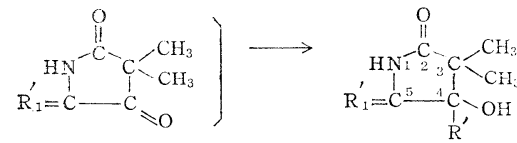

（1）とアジ化水素酸との 反応でも 1,4-付加と開環付 加とを経て 1:2 付加体をつくり，これがクルチウス分 解，水との反応により次のジアジドを生成する ${ }^{13)}$ 。

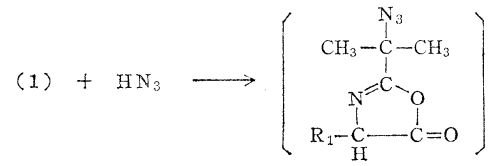

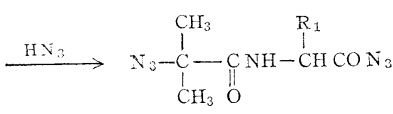

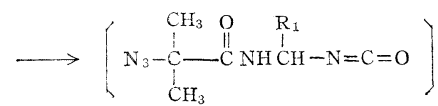

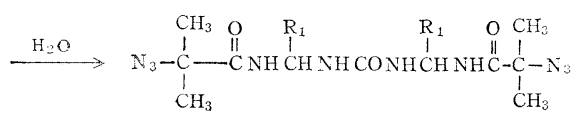

（1）はスチレンとラジカル共重合を行ない，1４４-重合 による共重会体を生成する ${ }^{5)}$ 。 $\mathrm{R}_{1}=\mathrm{CH}_{3}$ のプソイドオキ サゾロンは融点直下で $と$ 線による固相重合を行ない， 1 , 4-重合体至生成する ${ }^{13)}$ 。

（1）は酸素と 1:1 の共重合を行ない，ポリペルオキ シドを生成する。これより強靱なフィルムをつくること ができる，これは $60^{\circ} \mathrm{C}$ ぐらいまで安定であるが，それ 以上では爆発的に分解する。ポリペルオキドからの分解 生成物はアセトンとデヒドロ-NCA である ${ }^{14)} 。$

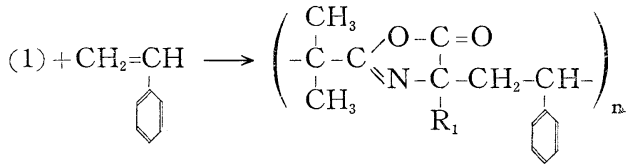

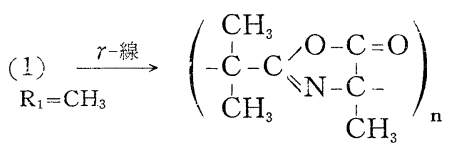

$$
\begin{aligned}
& (1)+\mathrm{O}_{2} \rightarrow\left(\begin{array}{c}
\mathrm{CH}_{3} \mathrm{CH}_{3} \\
\mathrm{C}-\mathrm{O}- \\
-\mathrm{O}-\stackrel{\mathrm{C}}{\mathrm{C}}
\end{array}\right)_{\mathrm{n}} \\
& \text { N Oे } \\
& \mathrm{R}_{1}-\ddot{\mathrm{C}}-\stackrel{\mathrm{C}}{\mathrm{C}}=\mathrm{O}
\end{aligned}
$$

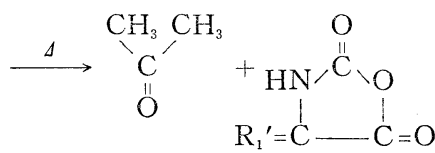

2. 機能団を有するモノマーの合成 種々の機能を もつ原子団を側鎖にもつビニル系およびノンビニル系の モノマーの合成が近時盛んに行なわれて拉り，官能性高 分子とか感応性高分子とか酵素モデルとか反応性高分子 とかいわれる高分子の合成に用いられる。

i. 核酸程基をむつビニルモノマーの合成 この問題 に関しては井本, 竹本両氏のすぐれた総説 ${ }^{15}$ があるので, これを活用させていただく。ここではプリン，ピリミジ ン，ヌクレオシドおよびヌクレオチドをふくむビニルモ ノマーおよび関連するノンビニルモノマーについて各論 的に解説する。

9-ビニルアデニン ${ }^{16)}$ : アデニンとエチレンカーボネー トとを水酸化ナトリウムの存在で DMF 中加熱して, 生 成する 9-(2-ヒドロキシエチル)-アデニン (mp 238〜 $239^{\circ} \mathrm{C}$ ，収率 $54 \%$ ）を塩化チオニルでクロル化し（収率 $75 \%$, mp 204 205ㅇ), ついでナトリウムメトキシド で脱塩酸して，9-ビニルアデニンを生成する。無色の結 晶で， mp 196 $197^{\circ} \mathrm{C}$, 収率 $60 \%$ である。

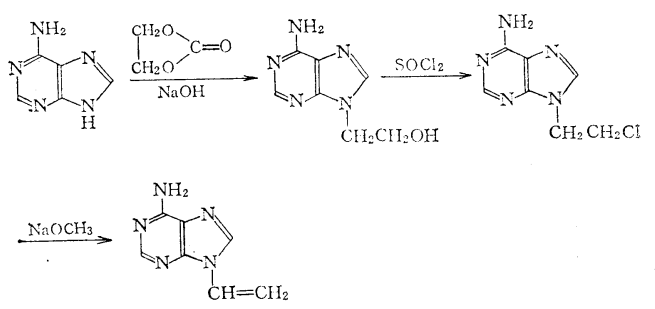

9-ビニルヒポキサンチン ${ }^{17)}$ : 9-(2-クロルエチル)-ア デニンから亜硝酸との反応で得られる 9-(2-クロルエチ ル)ーヒポキサンチン $\left(\mathrm{mp} 262^{\circ} \mathrm{C}\right)$ をジオキサン中ナトリ ウムメトキシドで脱塩化水素すると 9-ビニルヒポキサ 
( 49 )

ンチンが得られる。
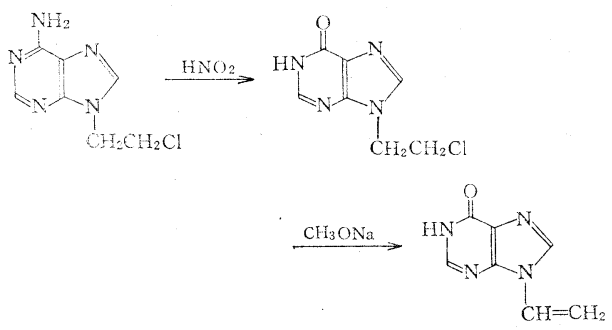

N-ビニル化反店に䣷酸水銀一硫酸を触媒とする酰酸ビ ニルによるビニル交換反応がある ${ }^{18)}$ 。その例学次に示 +े。

6-クロル-9-ビニルプリン ${ }^{19)}$ : 過䨋の酢酸ビニル中の 酢酸水銀けん濁に硫酸一酢酸エチル溶液を加え，この中 に 6-クロルプリンを加え，45〜 $50^{\circ} \mathrm{C}$ で反応させると N-ビニル化が進行し，6-クロル-9-ビニルプリンが得ら れる。融点 $166 \sim 167^{\circ} \mathrm{C}$, 収率 $70 \%$ である。

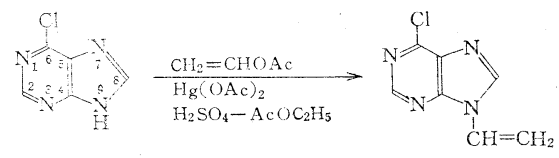

9-(2-メタクリロイルオキシエチル)-アデニン ${ }^{20)}: 9$ (2-ヒドロキシエチル)-アデニンとナトリウムヒドリド DMF 溶液を室温で反応させてナトリウム塩にしたのち メタクリロイルクロリドを加え，所期の化合物を合成す る。mp 201 203 $\mathrm{C}$, 收率 30\%。

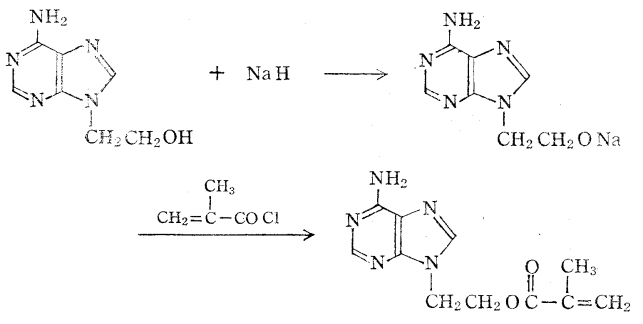

4-ビニルピリミジン ${ }^{21,22)}$ : 4-メチルピリミジンとパラ ホルムアルデヒドを封管中で加熱して生成した 4-(2-ヒ ドロキシエチル)ーピリミジン (bp $125 \sim 127^{\circ} \mathrm{C}(9 \mathrm{mmHg})$, 收率 76\%) 在少量の $p$-t-ブチルカテニールとともに $160^{\circ} \mathrm{C}$ に加熱した固体の $\mathrm{KOH}$ 上に㵜下し脱水して生成 する。bp $56 \sim 58^{\circ} \mathrm{C}(10 \mathrm{mmHg})$, 收率 $23 \%$ 。

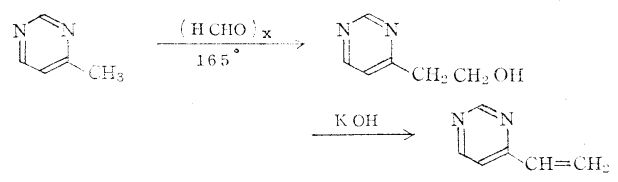

1-ビニルウラシル ${ }^{18)}: 2,4$-ビスー(トリメチルシリルオ

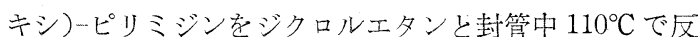
応させ，メタノール処理で得られる 1-(2-ヒドロキシエ チル)ーウラシル $\left(\mathrm{mp} 162 \sim 163^{\circ} \mathrm{C}\right.$, 収率 9\%) をカリウム -tーブトキシドで脱塩酸して合成する。 $\mathrm{mp} 181 \sim 182^{\circ} \mathrm{C}$, 収率 $42 \%$ 。

$$
\left(\mathrm{CH}_{2}\right)_{3} \mathrm{SiO}_{2} \frac{1) \mathrm{ClCH}_{2} \mathrm{CH}_{2} \mathrm{Cl}}{2) \mathrm{CH}_{3} \mathrm{OH}}
$$

ウラシルから次のようにして合成することすできるす<smiles>O=C(Cn1c(=O)cc[nH]c1=O)OCCO</smiles>
$\left(\mathrm{mp} 138^{\circ} \mathrm{C}\right.$ )<smiles>C=Cn1ccc(=O)[nH]c1=O</smiles>

もう1つの合成法があり，クロマト精製をともなら。<smiles>CCNC(=O)/C=C/OCC</smiles>

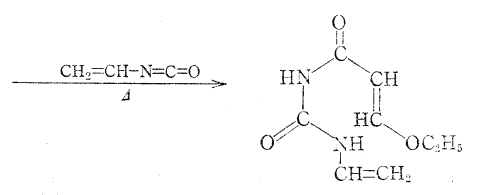<smiles>C=Cn1ccc(=O)[nH]c1=O</smiles>

1-ビニルチミン ${ }^{16)}$ : エチレンカーボネート法で 1-(2ヒドロ乎シエチル)-チミン $\left(m p 179 \sim 181^{\circ} \mathrm{C}\right.$, 収率 36\%)

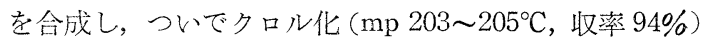
し，ナトリウムメトキシドで脱塩酸して合成する。水か ら再結晶, $\mathrm{mp} 205 \sim 207^{\circ} \mathrm{C}$ (昇華), 収率 $47 \%$ 。<smiles>C=Cn1cc(C)c(=O)[nH]c1=O</smiles> 
1-(2-メタクリロイル オキシエチル)-ウラシル20) : ヒ ドロキシエチルウラシルを $\mathrm{DMF}$-ピリジン中で $-50^{\circ} \mathrm{C}$ でメタクリロイルクロリドと反忘させ合成する。クロマ 卜精製を行なら。mp 99〜 $101^{\circ} \mathrm{C}$, 収率 44\%。1-(2-メ夕 クリロイルオキシエチル)-チミンも同様にして合成され る。 $\mathrm{mp} 163 \sim 165^{\circ} \mathrm{C}$ ，收率 $43 \%$ 。<smiles>[R]c1cn(CCO)c(=O)[nH]c1=O</smiles>

5'-O-アクリロイルウリジン ${ }^{23)}: 2^{\prime}, 3^{\prime}-\mathrm{O}, \mathrm{O}-イ ソ フ ゚ ロ$ ピリデンウリジンはアクリル酸無水物とピリジンの存在 で反忘し，アクリロイル誘導体となる。酸処理で 5'-Oアクリロイルウリジンを生成する。

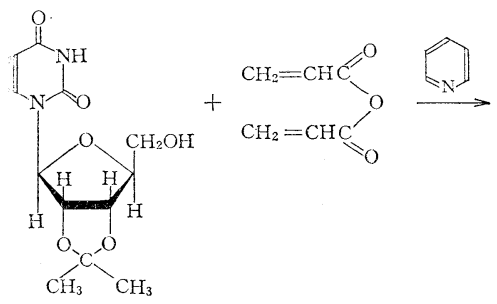

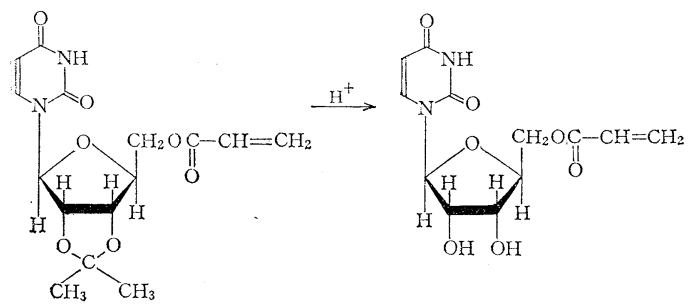

\section{1-〔2', 3', 4'-O-トリス（トリメチルシリル）-6'-メタク} 将ロイル- $\boldsymbol{\beta}-\mathbf{D}^{-}$グルコピラノシル]-チミン ${ }^{24)}: 1-(\beta-\mathrm{D}-$ グルコピラノシル)-チミンをピリジン中でトリメチルシ リル置換体とし， $\mathrm{K}_{2} \mathrm{CO}_{3}$ 触媒でメタノール中で $6^{\prime}$ 位の トリメチルシリル基をはずし，メタクリロイルクロリド でそのエステルにする。

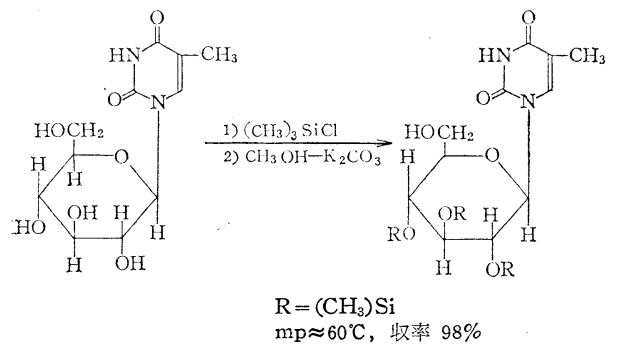

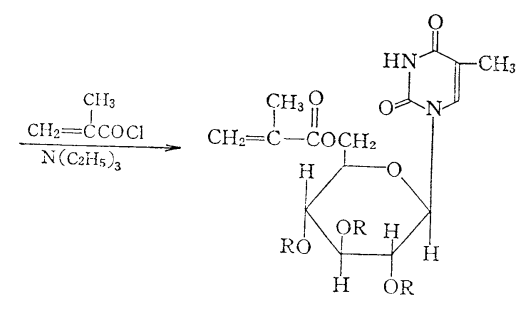

$\mathrm{mp} \approx 65^{\circ} \mathrm{C}$, 收率 $97 \%$

ほぼ同様な手法で，アデノシン，シチジンおよびウリ ジンのようなスクレオシドのモノメタクリロイルおよび ジメタクリロイル体が合成されている25)。

ビニル系化合物で注ないが，核酸塩基を含毛工ポキシ

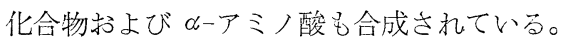

9-(2,3-エポキシプロピル)-アデニン 26): 酢酸中での アデニンとエピクロルとドリンとの反応で得られる 9(3-クロル-2-ヒドロキシプロピル)-アデニン $\left(\mathrm{mp} 180^{\circ} \mathrm{C}\right.$ (分解), 収率 $50 \%$ ) は水酸化アルカリ処理でエポキシ 環を生成する。吸湿性の粉末, 分解融点 $205^{\circ} \mathrm{C}$ 。
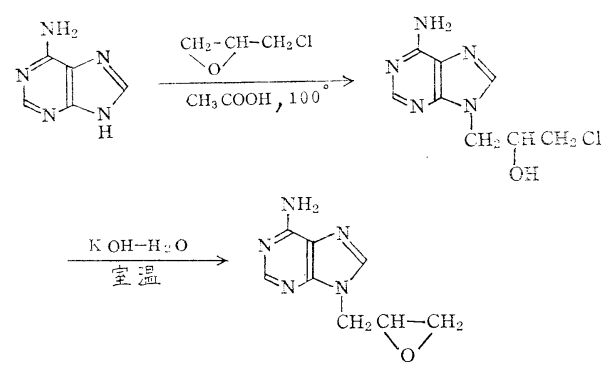

$\beta$-(2-オキソ-4-アミノ-1, 2-ジヒドロピリミジン-1-イ ル)-D,L-アラニン ${ }^{27)}: 4-\mathrm{N}-$ アセチルシトシンに DMF 中 炭酸カリウムとブロムアセタルデヒドジェチルアセター ルと $130^{\circ} \mathrm{C}$ で反応させ，ついでメタノールーアンモニア 処理で脱アセチル化し，得られる 1-(2,2-ジエトキシエ チル) シトシン $\left(\mathrm{mp} 232 \sim 234^{\circ} \mathrm{C}\right.$, 収率 $57 \%$ ) 是加水分 解してアルデヒド化合物にし, Strecker 合成により D, Lアラニン誘導体にする。

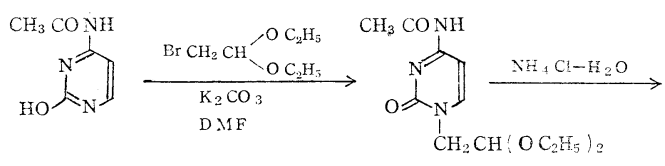<smiles></smiles>

同様にして $\beta$ - $(2,4$-ジオキソ-1, 2, 3, 4-テトラヒドロ ピリミジン-1-イル)-D, L-アラニンおよび $\beta-(6-ア ミ)$ プリン-9-イル)-アラニンが合成されている。 


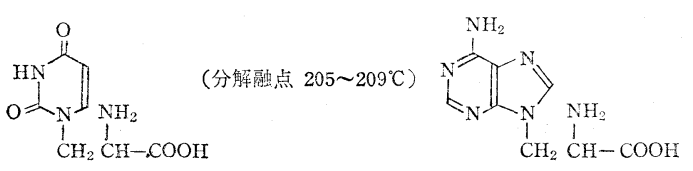

ii. 官能基をむつビニルモノマーの合成 感光性高分 子用のビニルモノマーの合成を述べる。

ベンソ゚インアクリレート ${ }^{28)}$ : ベンゾイン, ジメチルア ニリンのクロロホルム溶液にアクリル酸クロリドを滴下 し，還流する。生成物はエタノールより再結晶する。 $\mathrm{mp} 107^{\circ} \mathrm{C}$, 収率 $95 \%$ 。

$$
\curvearrowright \underset{\mathrm{O}}{\mathrm{O}}-\mathrm{ClC}-\mathrm{CH}=\mathrm{CH}_{2}
$$

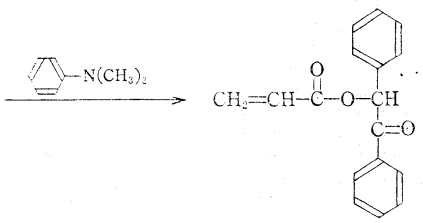

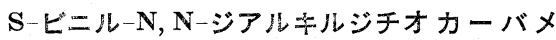
ート ${ }^{29)}$ : ジアルキルジチオカーバメートとジク ロルエタンとの反応でつくられたエチレンビス ( $\mathrm{N}, \mathrm{N}$-ジアルキルジチオカーバメート) の熱分 解を 2 3 $\mathrm{mmHg}$ 減圧で, $220 \sim 270^{\circ} \mathrm{C}$ で行なう と収率よく表題のモノマーが合成される。結果 を表 9 に示す。

$2 \mathrm{RRNC}-\mathrm{SK}+\mathrm{ClCH}_{2} \mathrm{CH}_{2} \mathrm{Cl}$

$$
\begin{aligned}
& \mathrm{S} \\
& \longrightarrow \text { RRNC-S-CH } \mathrm{CH}_{2} \mathrm{SCNRR}
\end{aligned}
$$

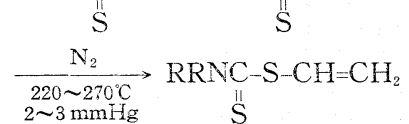

空 9 S-ビニル-N, N-ジアルキルジチオカーバメート

\begin{tabular}{l|c|r|c}
\hline \multicolumn{1}{c|}{$\mathrm{RRN}$} & 收率(\%) & $\mathrm{bp}{ }^{\circ} \mathrm{C}(\mathrm{mmHg})$ & $n_{\mathrm{D}}\left({ }^{\circ} \mathrm{C}\right)$ \\
\hline$\left(\mathrm{CH}_{3}\right)_{2} \mathrm{~N}$ & 90 & $82 \sim 83(2)$ & $1.6025(20)$ \\
$\left(\mathrm{C}_{2} \mathrm{H}_{5}\right)_{2} \mathrm{~N}$ & 95 & $93 \sim 94(1)$ & $1.5862(27)$ \\
$\left(n-\mathrm{C}_{3} \mathrm{H}_{7}\right)_{2} \mathrm{~N}$ & 84 & $117 \sim 118(2)$ & $1.5721(19)$ \\
$\left(n-\mathrm{C}_{2} \mathrm{H}_{9}\right)_{2} \mathrm{~N}$ & 98 & $130 \sim 132(2)$ & $1.5582(19)$ \\
$\langle-\mathrm{N}$ & 85 & $140 \sim 141(2)$ & $1.5918(19)$ \\
\hline- & & & \\
\hline
\end{tabular}

$\boldsymbol{p}$-ビニルフェニルシンナメート系モノマー- ${ }^{30,31)}: p$ ビニルフェノールは $p$-ヒドロキシアセトフェノンより 出発し，次のようにして合成される。<smiles>CC(=O)Oc1ccc(C(C)=O)cc1</smiles>

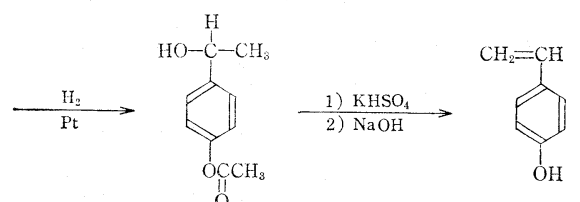

$p$-ビニルフェノールと桂皮酸類の酸クロリドとの反応 はピリジン中で行なう。結果 ${ }^{22}$ を表 10 に示す。

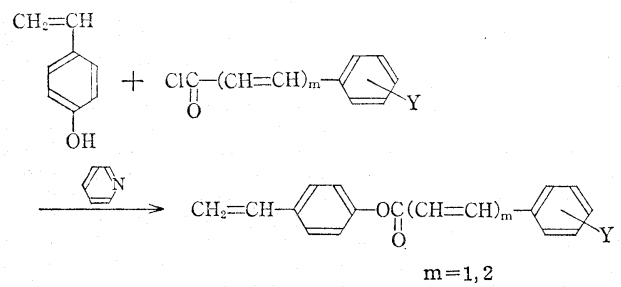

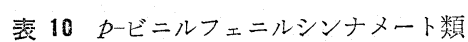

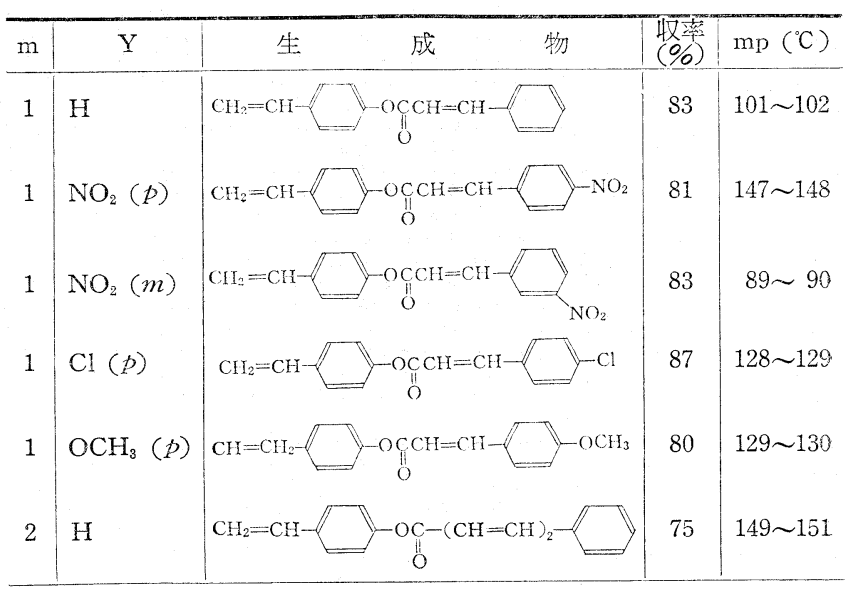

$m$-ビニルフェノールは $m$-ヒドロキシアセトフェノン から出発して合成され，pーイソプロペニルフェノールは 次式のようにビスフェノール A の熱分解で合成される。<smiles>C=C(C)c1ccc(O)cc1</smiles>

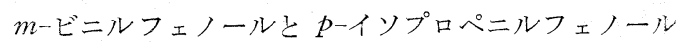
からを前と同様なシンナメートが合成される。結果 ${ }^{32}$ 究 表 11 に示す。

表 $11 m$-ビニルおよび $p$-イソプロペニル フェニルシンナメート類

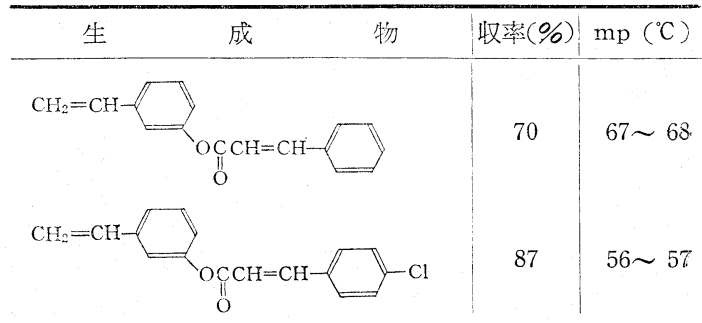




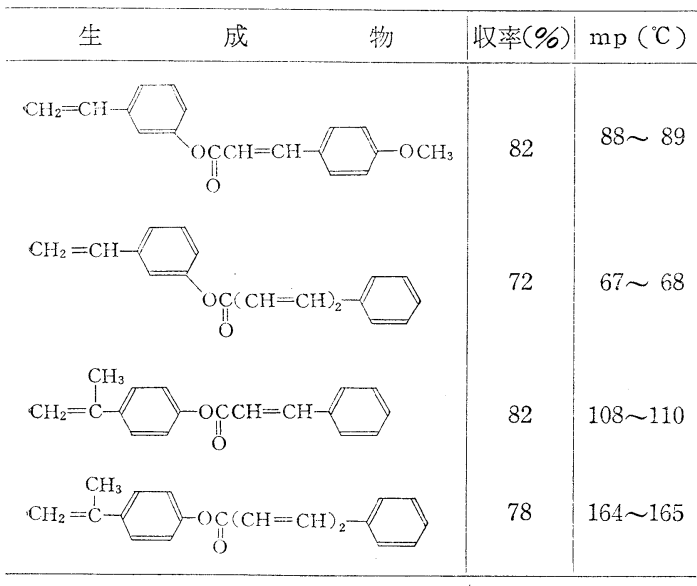

桂皮酸およびスチリルアクリル酸の $\beta$-ビニルオキシ エチルエステル : 2-クロルエチルビニルエーテルと桂皮 酸ナトリウム塩とをヨウ化トリエチルメチルアンモニウ ムとヒドロキノンの存在で加熱すると相当するエステル が好収率で合成される。結果 ${ }^{31.32)}$ を表 12 に示す。

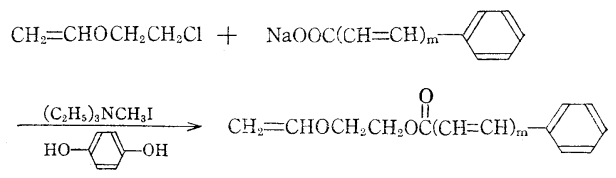

表 12 桂皮酸類の $\beta$-ビニルオキシエチルエステル

\begin{tabular}{|c|c|c|}
\hline 生 & $\begin{array}{l}\text { 双率 } \\
(\%)\end{array}$ & $\begin{array}{c}\mathrm{bp}{ }^{\circ \mathrm{C}} \\
(\mathrm{mmHg})\end{array}$ \\
\hline $\begin{array}{c}\mathrm{CH}_{2}=\mathrm{CHOCH}_{2} \mathrm{CH}_{2} \mathrm{OCCH}=\mathrm{CH} \\
\mathrm{O}\end{array}$ & 93 & $\begin{array}{r}116 \sim 118 \\
(0.05)\end{array}$ \\
\hline $\mathrm{CH}_{2}=\mathrm{CHOCH}_{2} \mathrm{CH}_{2} \mathrm{OCCH}=\mathrm{OH}-$ & 89 & $\begin{array}{r}120 \sim 125 \\
(0.05)\end{array}$ \\
\hline $\mathrm{CH}_{2}=\mathrm{CHOCH}_{2} \mathrm{CH}_{2} \mathrm{OC}-(\mathrm{CH}=\mathrm{CH}$ & 86 & $\begin{array}{r}145 \sim 150 \\
(0.2)\end{array}$ \\
\hline
\end{tabular}

ビニル基はカチオン触媒で重合させ, 後に光二量化さ せるシンナメートの二重結合は重合体中に完全に残そう とする上記の考え方のモノマーの合成をさらに㹡張さ せ，次式のようなモノマーがオキシカルコン誘導体とし て合成されている。

オキシカルコンの $\boldsymbol{\beta}$-ビニルオキシエチルエーテル ${ }^{31)}$ : オキシカルコンの合成は次の通りである。

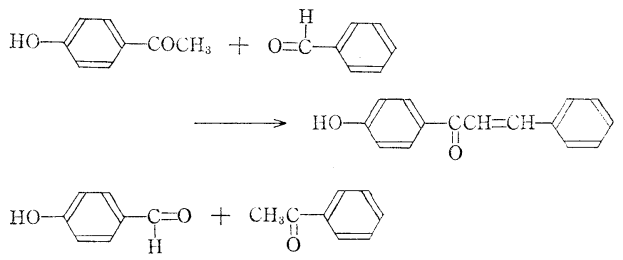

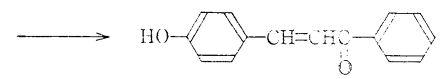

上記のナトリウム塩突ヨウ化トリエチルメチルアンモ ニウムの存在で 2-クロルエチルビニルエーテルと反応 させると次のモノマーが合成される。

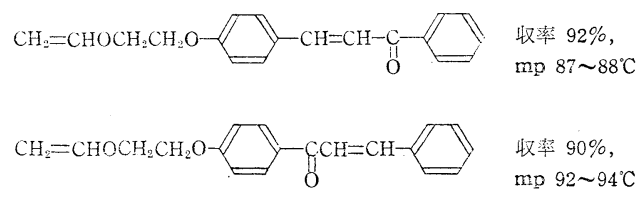

結晶状態で太陽光，高圧水銀灯やキセノン叔などの光 を照射すると光固相二量化反忘でシクロブタン環を形成 しつつポリマーを生成するようなモノマー(ジオレフィ ン化合物）が見出された。一般式 $\mathrm{Ar}^{\prime}-\mathrm{CH}=\mathrm{CH}-\mathrm{Ar}-\mathrm{CH}=$ $\mathrm{CHAr}^{\prime}\left(\mathrm{Ar}^{\prime}, \mathrm{Ar}\right.$ はともに芳香族環) 型および $\mathrm{RCOCH}=$ $\mathrm{CH}-\mathrm{Ar}-\mathrm{CH}=\mathrm{CHOCR}$ ( $\mathrm{R}$ は OH, $\mathrm{OCH}_{3}, \mathrm{OC}_{2} \mathrm{H}_{5}, \mathrm{OCH}_{-2}$ $\left.\mathrm{CH}_{2} \mathrm{CH}_{3}, \mathrm{OCH}\left(\mathrm{CH}_{3}\right)_{2}, \mathrm{O} \longrightarrow, \mathrm{NH}_{2}\right)$ 型のジオレフィ ンである ${ }^{33)}$ 。

trans, trans-2, 5-ジスチリルピラジン : 2,5-ジメ チルピラジンとベンザルデヒドを塩化亜鉛の存在で脱水 縮合させて合成する。

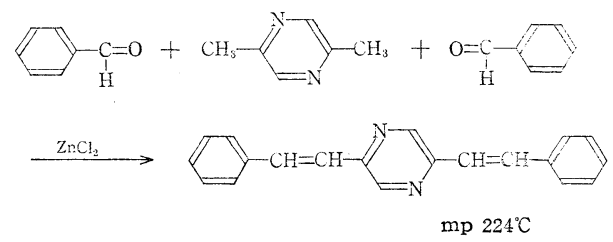

$\operatorname{trans,\operatorname {trans}-1,4-ビス~[\beta -ビリジル-(2)-ビニル]~}$ ベンゼン：これは次のようにWittig 反応により合成さ れる。

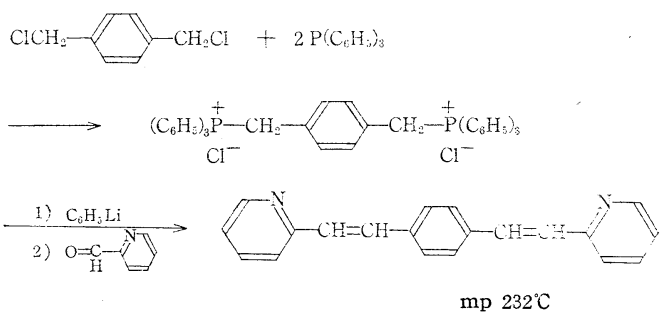

p-フェニレンジアクリル酸および誘導体 : テレフタル アルデヒドとマロン酸をピリジンの存在下反応させると pーフェニレンアクリル酸が生成する ${ }^{33)}$ 。

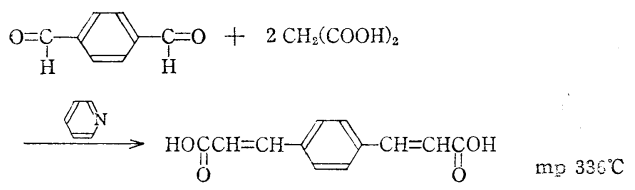


このジカルボン酸をジクロリドとしメタノール，エタ タール，n-プロパノール，iso-プロパノール，フェノー ルかよびアンモニアとアルカリの存在で反応させると相 当するジメチル $\left(\mathrm{mp} 171^{\circ} \mathrm{C}\right)$, ジエチル $\left(\mathrm{mp} 94^{\circ} \mathrm{C}\right)$, ジ n-プロピル $\left(\mathrm{mp} 73^{\circ} \mathrm{C}\right)$, ジ-iso-プロピル $\left(\mathrm{mp} 84^{\circ} \mathrm{C}\right)$ お よびジフェニルェステル $\left(\mathrm{mp} 165^{\circ} \mathrm{C}\right)$ とアミド $(\mathrm{mp}$ $320^{\circ} \mathrm{C}$ ) が合成される。

光により吸収スペクトルの可逆的变化を行なうすなお ち Phototropy または Photochromism を行なら高分子 (フォトクロミック高分子またはカメレオン高分子) を 合成する目的で，そのモノマーの合成研究が行なわれて いる。モノマーとしてはアミノアゾベンゼン系のものが 合成されている ${ }^{34)}$ 。

それらの原料モノマーとしては $p$ ーアミノスチレン, m-ジメチルアミノスチレンおよび $o$ ーヒドロキシスチレ ンが用いられ，その合成法は次の通りである。

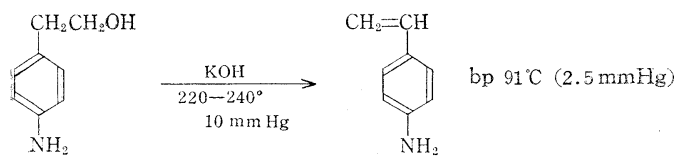<smiles>CC(=O)c1cccc(C=O)c1</smiles>

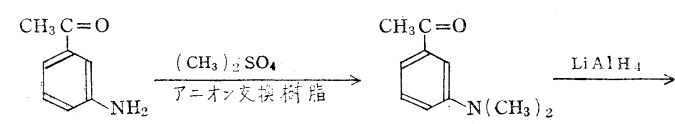<smiles>CN(C)c1cccc(C(C)(C)C)c1</smiles>
(bp $105^{\circ} \mathrm{C} / 2 \mathrm{mmHg}$ )

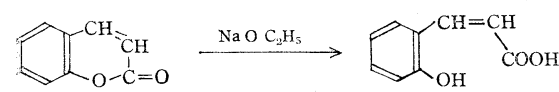<smiles>C=Cc1ccc(C2CC2)cc1O</smiles>

アミノアゾベンゼン系フォトクロミックモノマー : 4ビニル-4'-アミノアゾベンゼン誘導体は $p$-アミノスチ ンンのジアゾ化物を酢酸酸性でジメチルアニリンやアニ リンと反応させて合成する。

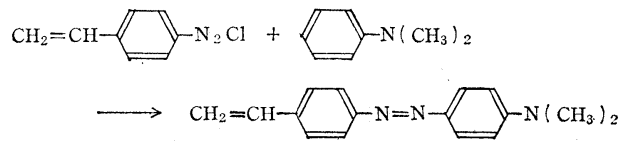

$\operatorname{mp~} 132 \sim 134^{\circ} \mathrm{C}, \lambda_{\max } .428 \mathrm{~m} \mu$

$$
\longrightarrow \mathrm{N}_{2} \mathrm{Cl}+\mathrm{CH}_{2}=\mathrm{CH}
$$

2-ビニル-4-ジメチルアミノアゾベンゼン誘導体は $m$-ジメチルアミノスチレンにジアゾ化合物をカップリ ングして合成する。

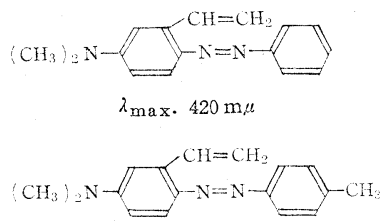

油状, $\lambda_{\text {max }} .423 \mathrm{~m} \mu$
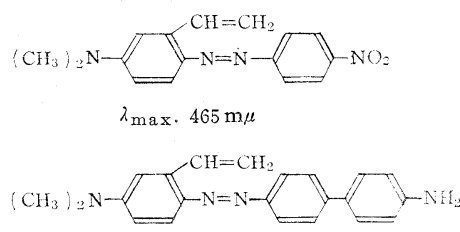

$\operatorname{mp} 55 \sim 57^{\circ} \mathrm{C}, \lambda_{\max } \cdot 429 \mathrm{~m} \varepsilon$

3-ビニル-4-ヒドロキシアゾベンゼン誘導体は $o$-ヒド ロキシスチレンにジアゾ化合物をカップリングして合成 する。
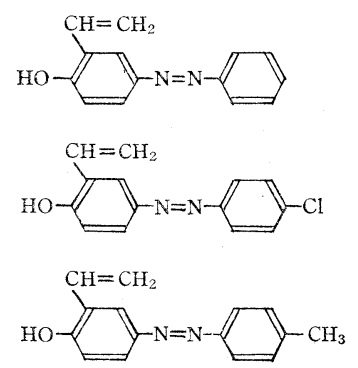

\begin{tabular}{c|c}
\hline $\mathrm{mp}(\mathrm{C})$ & $\lambda_{\max }(\mathrm{m} \mu)$ \\
\hline $105 \sim 106$ & 350 \\
$134 \sim 135$ & 358 \\
$138 \sim 139$ & 355 \\
\hline
\end{tabular}

N-アクリルアミドメチルアミノアゾベンゼン誘導体 は次のようにして合成する。

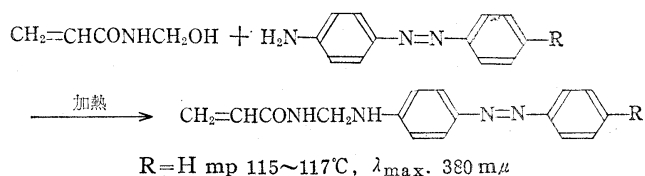

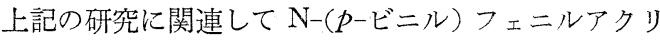
ルアミドが合成されている゙5)。

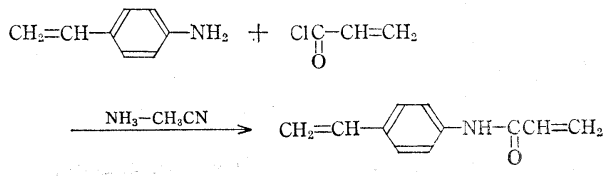


エタノールー水から再結晶, $\mathrm{mp} 128 \sim 130^{\circ} \mathrm{C}$, 収率 $69 \%$ 。

2-オキサゾリドン環をむつモノマー：オキサゾリド ン環はフェノール，メチルブロミドおよび八ロゲンと complex を生成するので，これを含むモノマーの合成が 行なわれている。2-オキサゾリドンの N-ナトリウム塩 をつくり，これにアクリル酸クロリドのクロロホルム溶 液を加え, $60^{\circ} \mathrm{C}$ で反応させる。生成物は真空蒸留で精製 する ${ }^{36)}$ 。 bp $102^{\circ} \mathrm{C}(0.14 \mathrm{mmHg}), \mathrm{mp} 52 \sim 53^{\circ} \mathrm{C}$, 収率 $25 \%$ 。

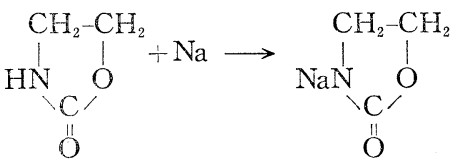<smiles>O=C(Cl)C=CC(=O)N1CCOC1=O</smiles>

Nーグリシジル-2-オキサン゙リドン : 2-オキサゾリドン の N-ナトリウム塩にエピクロルヒドリンの THF 溶液 索加え, $60^{\circ} \mathrm{C}$ で反応させる。生成物は減圧蒸留で 精製 する ${ }^{37)}$ 。 bp $107 \sim 108^{\circ} \mathrm{C}(0.1 \mathrm{mmHg})$, 収率 $41 \%$ 。
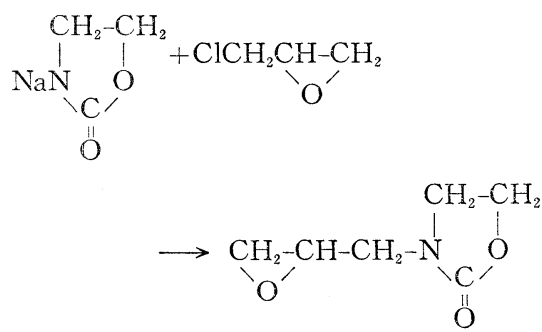

オキサゾール環をもつモノマー：電導性または光電導 性をもつ高分子の合成を期待して 2-ビニルー4, 5-ジフェ ニルオキサゾールがベンゾインアクリレートを䣷酸アン モニウムあるいは尿素を䣫酸中で反応させる方法とアク リロニトリルとベンゾインとを濃硫酸中で反応させる方 法で合成された

$$
\begin{aligned}
& \mathrm{CH}_{2}=\mathrm{CH}
\end{aligned}
$$

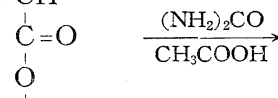

$$
\begin{aligned}
& \mathrm{CH}_{2}=\mathrm{CH} \\
& \mathrm{N}^{\mathrm{C}} \mathrm{O}
\end{aligned}
$$
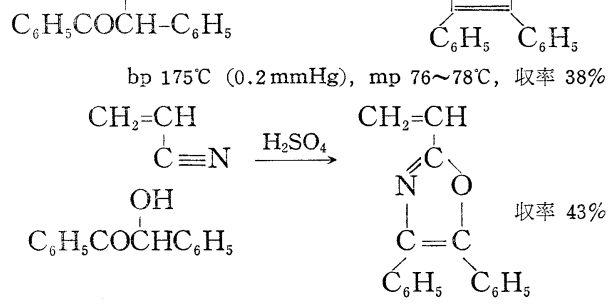

このモノマーからのポリマーは予期した光電導性など
示さなかったが, $300 \mathrm{~m} \mu$ の紫外線照射により $\lambda_{\max } .408$ $\mathrm{m} \mu$ のイイ光スペクトルを示し, シンチレーターとして の期待がもたれている。

エレクトロントランスファーポリマーのためのモノマ 一の合成研究は引き続き行なわれている。

1-ビニル-3, 4, 6-トリメチル-2-メトキシ-5-ヒドロキ シベンゼン ${ }^{39)}$ : 1-クロルメチル-5-ヒドロキシ-2-メトキ シー3, 4, 6-トリメチルベンゼンを原料とし，トリフェニ ルホスフィンとの反応で相当するトリフェニルホスホニ ウムクロリドとし，これを THF 中で $n$-ブチルリチウム で処理したあとトリオキサンを加えビニル化する。黄色 結晶, $\mathrm{mp} 67 \sim 68^{\circ} \mathrm{C}$ ，カチオン重合を行なう。

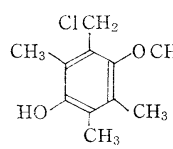

$\mathrm{Cl}$ $\left(\mathrm{C}_{6} \mathrm{H}_{5}\right)_{3} \mathrm{P}^{+} \mathrm{CH}_{2}$<smiles>CCCCCc1c(C)c(O)c(C)c(C)c1OC</smiles>
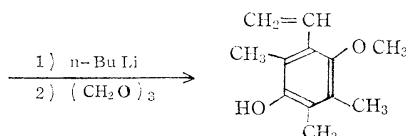

$\mathrm{CH}_{3}$

3-メタアクリロイルメチル-5, 7, 8-トリメチルクロマ

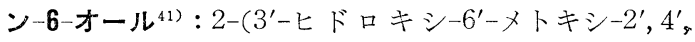
5'-トリメチルベンジル)-プロパン-1, 3-ジオールからつ くられた 3-ヒドロキシメチル $-5,7,8$-トリメチルクロマ ンー6-オールと濃硫酸の存在で過剰のメチルメタクリレ 一トとエステル交換反応を行なわせると所期のモノマー が合成される。生成物はアセトニトリル水溶液から再結 晶され， $\mathrm{mp} 100 \sim 101^{\circ} \mathrm{C}$, 収率 $69.8 \%$, ラジカル重合さ れる。

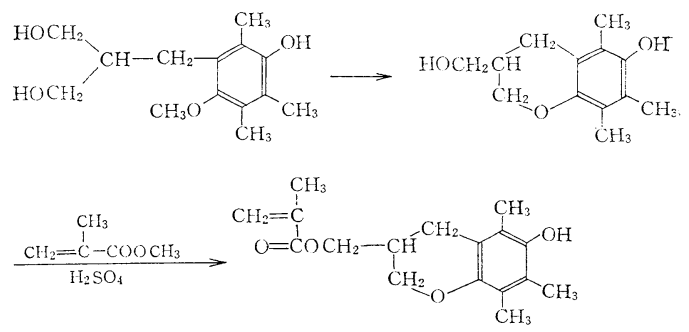

ビニル-(2,5-ジアセトキシフェニル) スルホン ${ }^{40)}$ : 次 式に示す方法で合成され，mp $86.5 \sim 88^{\circ} \mathrm{C}$ ，収率 $90 \%$ 。

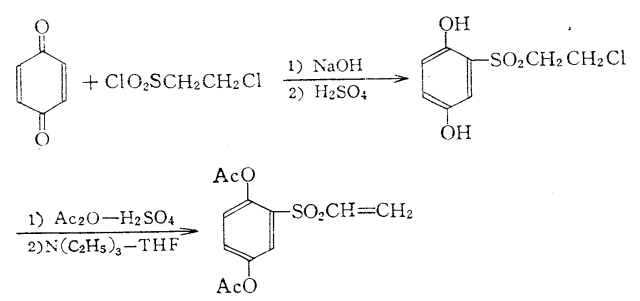


化学反忘性を一つの機能と考え, 反応性を有する原子 団をもつ反応性モノマーの合成研究も引き続き行なわれ ている。この重合体はいわゆる反応性高分子である。

$p$-スチレンスルホニル $\left(\boldsymbol{\beta}\right.$-クロルエチル) アミド ${ }^{42)}$ : p-スチレンスルホン酸カリウムと五塩化りンとの反灾 で相当するスルホニルクロリドにし，これにトリエチル アミンの存在でエチレンイミンを反応させてスルホニル アジリン化合物上し，ついで濃塩酸で開環付加する。生 成物は石油エーテルより再結晶, $\mathrm{mp} 77.5 \sim 78.5^{\circ} \mathrm{C}$, 中 間体のスルホニルアジリジンは不安定で変化し易い。

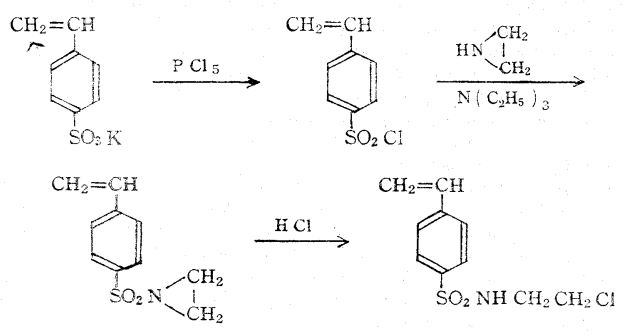

アリルスルホニルクロルエチルアミド(3) : アリルスル ホニルクロリドとエチレンイミンとの反応で合成され る。 bp $132.5 \sim 133.5^{\circ} \mathrm{C}(1 \mathrm{~mm} \mathrm{Hg}), \mathrm{mp} 35.5 \sim 35^{\circ} \mathrm{C}$ 。

$$
\begin{aligned}
\mathrm{CH}_{2}=\mathrm{CH}-\mathrm{CH}_{2} \mathrm{SO}_{2} \mathrm{Cl}+\mathrm{HN}^{-} \stackrel{\mathrm{CH}_{2}}{\mathrm{CH}_{2}} & \stackrel{\mathrm{CH}_{2}}{\longrightarrow} \mathrm{CH}_{2}=\mathrm{CH}-\mathrm{CH}_{2}-\mathrm{SO}_{2} \mathrm{NHCH}_{2} \mathrm{CH}_{2} \mathrm{Cl}
\end{aligned}
$$

ビニルスルホニル $\left(\boldsymbol{\beta}\right.$-クロルエチル) アミド ${ }^{44)}:$ ビニ ルスルホニルエチレンイミドと塩酸との反応で合成す る。bp $139.5 \sim 140.5^{\circ} \mathrm{C}(2 \mathrm{mmHg})$, 収率 $35 \%$ 。

$$
\begin{aligned}
& \mathrm{CH}_{2}=\mathrm{CHSO}_{3} \mathrm{Na} \stackrel{\mathrm{PCl}_{5}}{\longrightarrow} \mathrm{CH}_{2}=\mathrm{CH}-\mathrm{SO}_{2} \mathrm{Cl}
\end{aligned}
$$

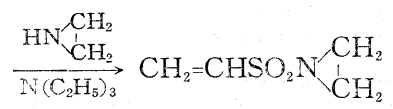

$$
\begin{aligned}
& \stackrel{\mathrm{HCl}}{\longrightarrow} \mathrm{CH}_{2}=\mathrm{CHSO}_{2} \mathrm{NHCH}_{2} \mathrm{CH}_{2} \mathrm{Cl}
\end{aligned}
$$

$p$-スチレンカルボン酸グリシジルエステル ${ }^{45)}: p-(\beta-$ ブロモエチル）安息香酸安エタノール中水酸化カリウム と反忩させて $p$-スチレンカルボン酸カリウム塩とし, これを過剩のエピクロルヒドリンとハイドロキノン, ト リエチルベンジルアンモニウムクロリドの存在で反応さ せ，相当するグリシジルエステルを合成する。 bp 115.5 $\sim 116.5^{\circ} \mathrm{C}(0.1 \mathrm{~mm} \mathrm{Hg}), n_{\mathrm{D}}^{20} 1.5622$ 。

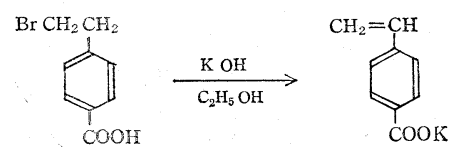

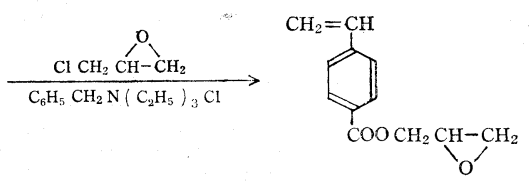

p-イソシアナートスチレンおよび 誘導体 ${ }^{45)}:$ - $p$-スチ レンカルボン酸と塩化チオニルとの反応で, $p$-スチレン カルボン酸クロリドをつくり，これとナトリウムアジド との反応でできる p-スチレンカルボン酸アジドをトル エン中 $80^{\circ} \mathrm{C}$ でクルチウス分解する。 $p$-イソシアナート スチレン (2)の bp は $40.5 \sim 41.5^{\circ} \mathrm{C}(0.1 \mathrm{~mm} \mathrm{Hg}), n_{\mathrm{D}}^{20}$ 1.5785 である。

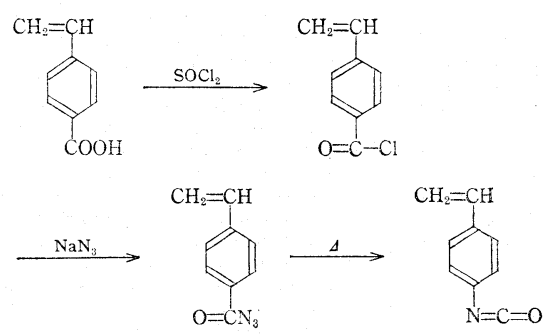

（2）にグリシドールを作用させると相当するグリシジ ルウレタンを生成する。 $\mathrm{mp} 95.5 \sim 97^{\circ} \mathrm{C}$ 。

(2) $+\mathrm{HOCH}_{2} \mathrm{CH}_{\mathrm{O}^{\prime}}-\mathrm{CH}_{2} \longrightarrow$<smiles>C=Cc1ccc(NC(=O)OCC)cc1</smiles>

（2）とエチレンイミンとの付加反応では相当するエチ レン尿素化合物を生成する。 $\mathrm{mp} 108.0 \sim 108.5^{\circ} \mathrm{C}$ 。<smiles>[13CH3]CN[TeH4]</smiles><smiles>C=Cc1ccc2c(c1)C(=O)N2</smiles>

グリシジルメチルイタコネート ${ }^{46)}:$ メルナトリウイ タコネートをトリエチルベンジルアンモニウムクロリド を触媒とし，エピクロルヒドリンと反応させるとグリシ ジルエステルが生成する。bp $106 \sim 108^{\circ} \mathrm{C}(0.5 \mathrm{mmHg})$, $n_{\mathrm{D}}^{20} 1.4632$ 。

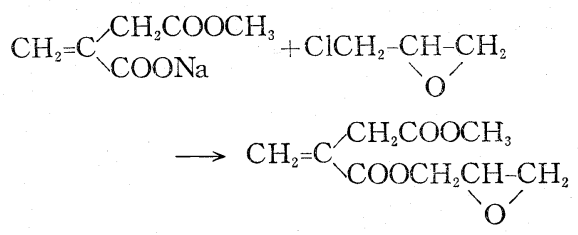

メタクリル酸エステル型重合性染料および中間体 ${ }^{47)}$ : グリシジルメタクリレートの化学反応性を利用し, 各種 の重合能をもつ染料中間体および染料が合成された。結 
果を表 13 亿示す。

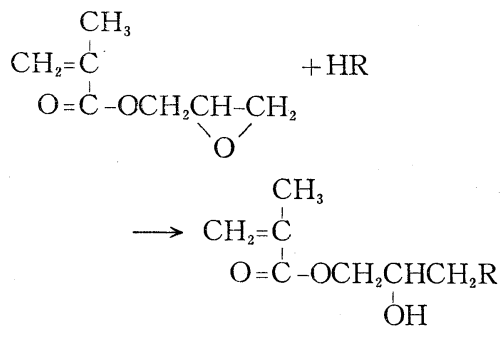

表 13 重合性染料中間体および染料*

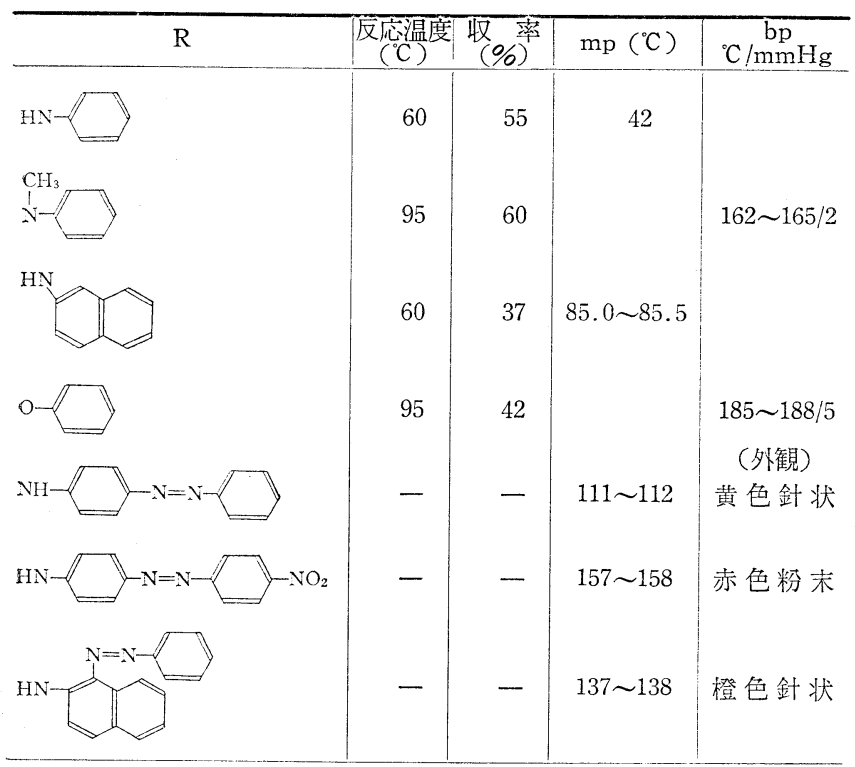

*染料は中間体にジアゾ化合物をカップリングして合成

糖を含むメタクリル酸エステル48)：次のような各種の 糖を含むメタクリレートおよびアミドが合成された。

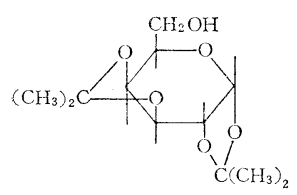

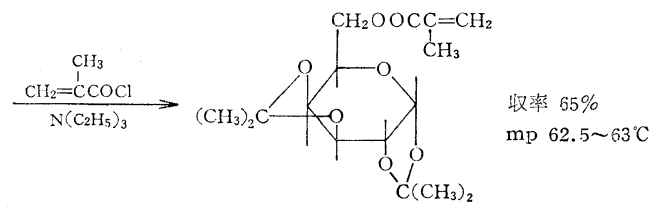

1, 2,3,4-ジ-O-イソプロピリデン-6-O-メタクリ ロイルーDーカ゚ラクトース

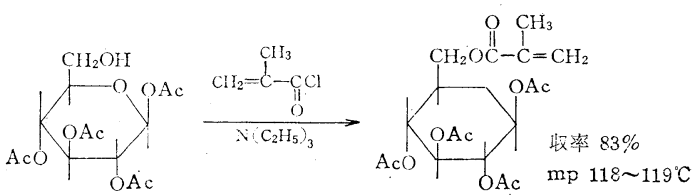

1, 2,3,4-テトラ-O-アセチル-6-O-メタクリロイル-D-グルコース

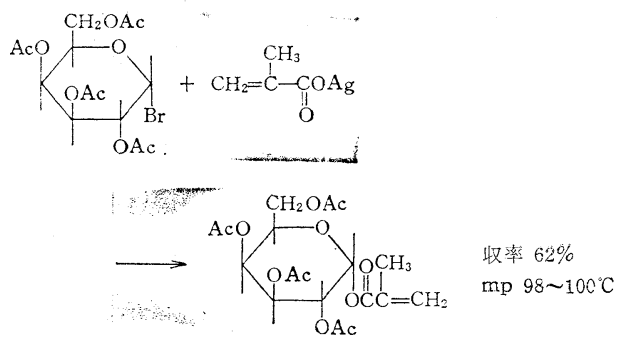

1-O-メタクリロイル-, 2, 3, 4, 6-テトラ-O-アや チルーD-ガラクトース
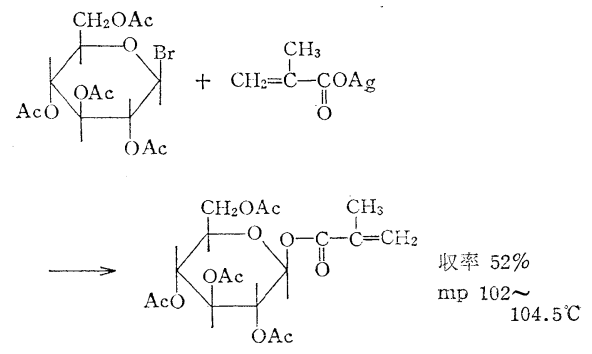

1-O-メタクリロイル-2, 3, 4, 6-ラトラーーーーア セチルーDーグルコース

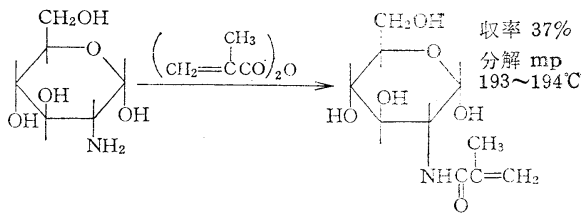

N-メタクリロイル-D-グルコサミン

メルカプト基をもつポリマーのプリカーサー としてメタクリロイルオキシアルキルイソチウロニウム 塩が合成されている。イソチウロニウム塩はアルカリに よりメルカプタンに分解する。

2-[2-(メタクリロイルオキシ) エチル]イソチウロニ ウム $\boldsymbol{p}$-トルエンスルホネート ${ }^{49)}$ : 次式のように合成さ れる。<smiles>C=C(C)C(=O)OCCO</smiles><smiles>CC(=Cc1ccccc1)C(=O)OCCOc1ccc(C)cc1</smiles><smiles>CCCCC(=O)C(C)CCC(=O)C(N)=CN</smiles>
同様にして次の化合物が合成されている。 


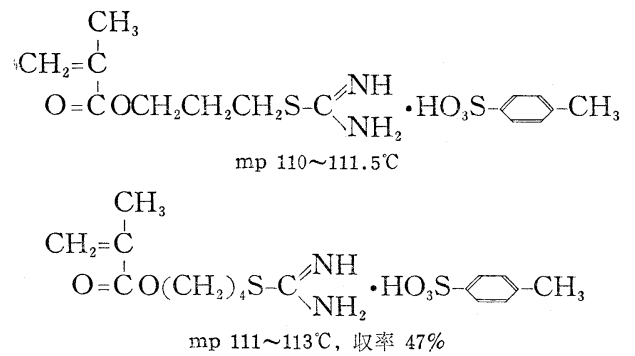

$\boldsymbol{p}$-ビニルフェニルジメチルシラン ${ }^{50)}: \mathrm{SiH}$ を含をビ ニルモノマーで, $\mathrm{SiH}$ の化学反応性を利用できるポリマ 一の合成が行なわれている。

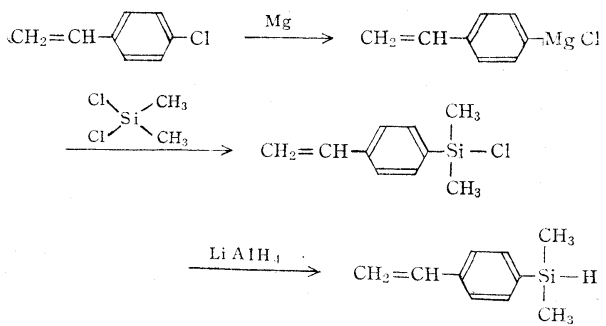

bp $48^{\circ} \mathrm{C}(0.8 \mathrm{mmHg})$

このモノマーは ABIN で $60^{\circ} \mathrm{C}$ でラジカル重合し， ポ リマー側鎖の $\mathrm{SiH}$ は $\mathrm{KOH}$ の存在下エトキシ化される。

ゲルマニウムを含むモノマー合成も行なわれている。

トリメチルビニルゲルマン ${ }^{51)}$ : グリニャ一反応により 次のようにして合成される。

$$
\begin{aligned}
\mathrm{CH}_{3} \mathrm{MgBr}+\mathrm{GeCl}_{4} & \longrightarrow\left(\mathrm{CH}_{3}\right)_{4} \mathrm{Ge} \\
3\left(\mathrm{CH}_{3}\right)_{4} \mathrm{Ge}+\mathrm{GeCl}_{4} & \longrightarrow 4\left(\mathrm{CH}_{3}\right)_{3} \mathrm{GeCl} \\
\left(\mathrm{CH}_{3}\right)_{3} \mathrm{GeCl}+\mathrm{CH}_{2} & =\mathrm{CHMgCl} \\
& \longrightarrow \mathrm{CH}_{2}=\mathrm{CHGe}\left(\mathrm{CH}_{3}\right)_{3}
\end{aligned}
$$

bp $67 \sim 72^{\circ} \mathrm{C}$ のモノマーが $61.5 \%$ の収率で得られる。 nーブチルリチウム触媒で低重合体を与える。

ガラス転移温度と耐熱性の向上を目的に Si をふくを ビニルモノマーが合成されている。

ビニル $\boldsymbol{p}$-トリメチルシリルベンゾエート ${ }^{52)}: p-ト リ$ ルトリメチルシランをピリジン中で酸化して相当するカ ルボン酸にし，これを過剩の酢酸ビニルと酢酸水銀, $20 \%$ 発煙硫酸を触媒として反忘させビニル交換反忘を行な う。最高収率 $79 \%$, bp $120^{\circ} \mathrm{C}(8 \mathrm{mmHg}), n_{\mathrm{D}}^{20} 1.5159$ 。

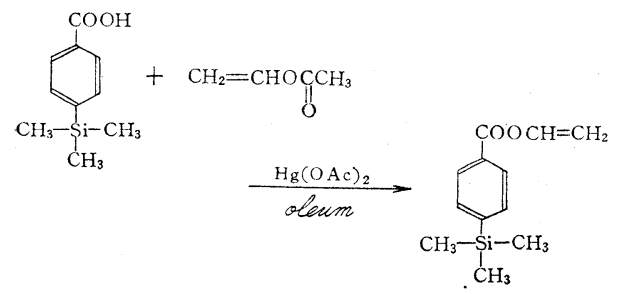

光学活性 $\mathbf{N}-$ ボルニルマレイミド53) : 無水マレイン酸
といーカンファーアミンとから次のようにして合成され る。
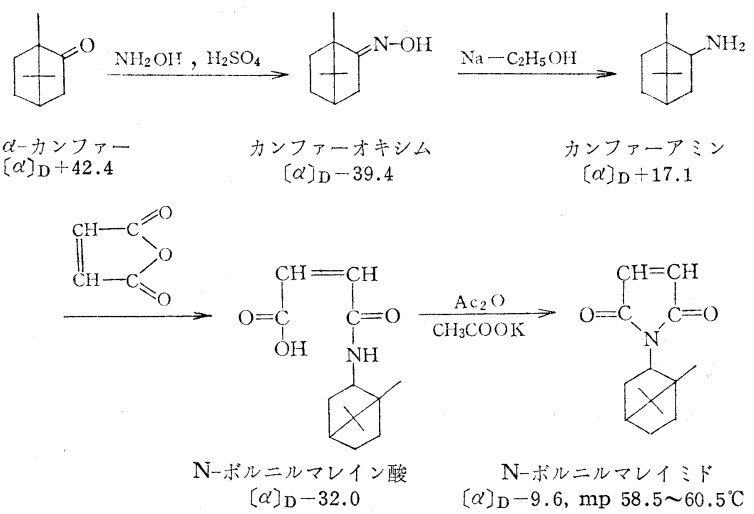

触媒作用をもつ高分子合成のためのモノマーとして, ビニルイミダゾールとの類似性が期待されるどニルトリ アゾールの合成が行なわれている。

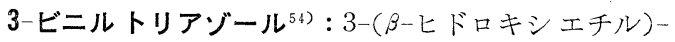
1,2,4-トリアゾールはあらかじめ活性化されたモレキュ ラーシーブ A と混合し，280 $300^{\circ} \mathrm{C}$ の油浴中で加熱さ れる。ついで $0.5 \mathrm{mmHg}$ 下蒸留され, 蒸留物は凍結乾燥 される。3-ビニル-1, 2, 4-トリアゾールは $\mathrm{mp} 38 \sim 40^{\circ} \mathrm{C}$ で，収率 10〜15\% で合成された。<smiles>C=Cc1nc[nH]n1</smiles>

2-フェニル-5-(4'-ビニル) フェニルテトラゾール このビニルモノマーは次式のよらにポリマーになったと き 1 種の反応性高分子になり得るはずであるが，なおこ のものは 1,3-双極成環重合を行なって高分子も生成す る。モノマーの合成法は次の通りである。

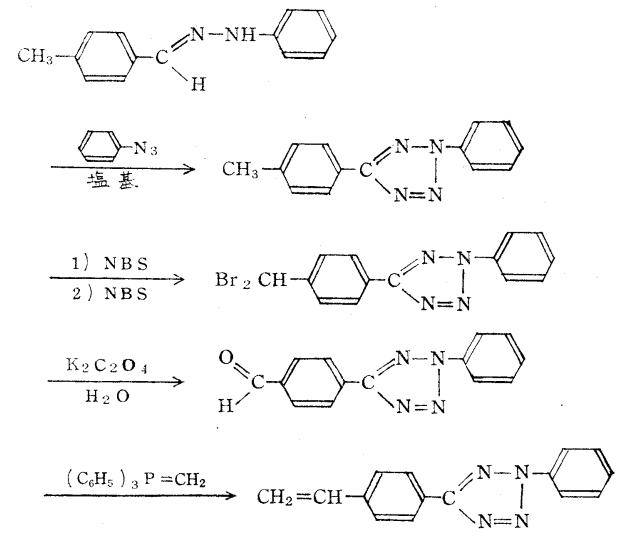

(3) 
(3)
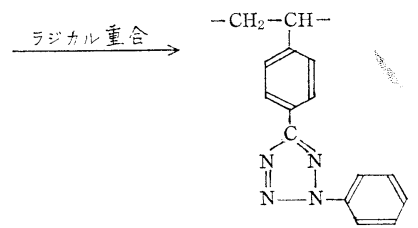

(3)

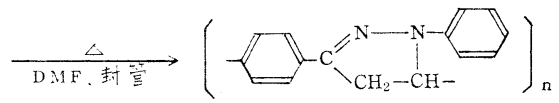

リビング重合の研究のために次のような芳香族性複素 環モノマーの合成が行なわれた。

3-イソプロペニルイソキサゾール4) : オキシイミノク ロル酶酸エチルエステルと 3 倍モルの酶酸ビニルを用い ての 1,3-双極成環付加は THF 中で行なら。生成物は $106^{\circ} \mathrm{C}$ で加熱し脱酶酸を行ない，減圧蒸留で精製する。 定量的に得られた 3-カルボエトキシイソキサゾールに $\mathrm{CH}_{3} \mathrm{MgI}$ を作用させ，ついで生成したカービノールをポ リリン酸と $120^{\circ} \mathrm{C}$ で反応させ脱水する。 bp $76^{\circ} \mathrm{C}$ (50 $\mathrm{mmHg}), n_{\mathrm{D}}^{20} 1.4796$ 。

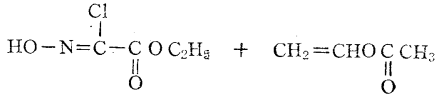

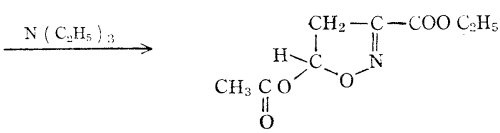

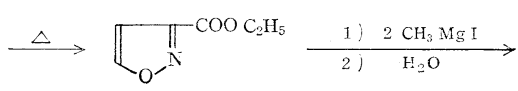

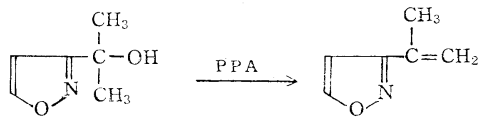

2-イソプロペニル-1, 3,4-オキサジアゾール4) $: \mathrm{N}-$ ア セチル-N-メタクリロイルヒドラジン (mp 128 129 $\left.{ }^{\circ} \mathrm{C}\right)$ を PPA 中で脱水。bp $134^{\circ} \mathrm{C}(13 \mathrm{mmHg}), \mathrm{mp} 46^{\circ} \mathrm{C}$ 。

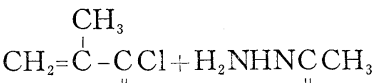

$$
\begin{aligned}
& \text { OI } \mathrm{O} \\
& \mathrm{CH}_{3} \\
& \stackrel{\mathrm{NaOH}}{\longrightarrow} \mathrm{CH}_{2}=\stackrel{\mathrm{C}}{\mathrm{C}}-\mathrm{C} \mathrm{NHNHCCH}_{3} \\
& \text { OI } \stackrel{\| 1}{\mathrm{O}}
\end{aligned}
$$

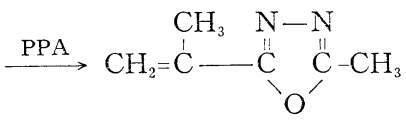

触媒作用の研究も含めて，2-イソプロペニル，4-ビニ ルおよび 4-イソプロペニルチアゾールが合成された ${ }^{56)} 。$
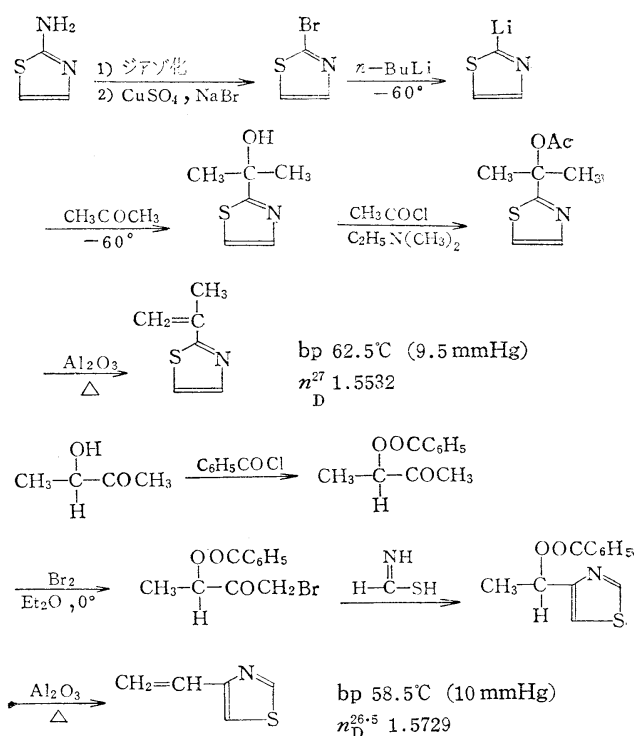

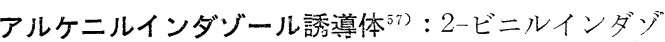
一ルがインダゾールを酢酸水銀と発煙硫酸の存在下過剩 の酶酸ビニルと加熱するとビニル交換して生成する。収 率 $73 \%$ 。

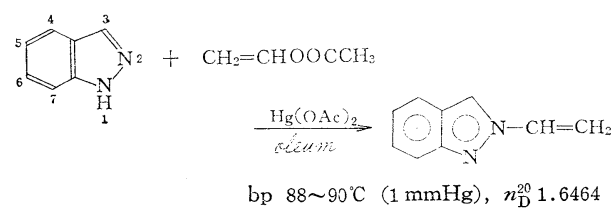

インダゾール-3-カルボン酸と過剩の酢酸ビニルを酢 酸水銀と $20 \%$ 発煙硫酸およびキノンとともに反応させ るとイソダゾールー1-アセチル-3-カルボン酸ビニルエス テルが生成する。 $\mathrm{mp} 120 \sim 121^{\circ} \mathrm{C}$ ，粗収率 $84 \%$ 。

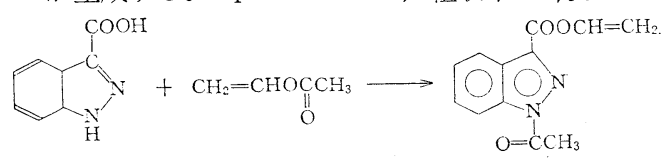

ポリラジカルアニオンやポリジアニオン合成のための 原料モノマーとして p-ビニルトランススチルベンや5s》 次のようなものが合成されている。

9-[2-ビニルフルオレニリデンメチル]-フルオレン ${ }^{59)}$ : 2-アセチルフルオレンの $\mathrm{NaBH}_{4}$ 還元により，フルオレ ニルー(2)-メチルカービノールをつくり，ついでこれを 減圧下 $350^{\circ} \mathrm{C}$ でアルミナ上で脱水反応を行ない，生成京 る 2-ビニルフルオレンはベンゼンより再結晶をくりか えし精製する。当量の 2-ビニルフルオレンとビフェニ レンビニルブロミドとを DMSO 中にとかし， $2 N$ の水 酸化ナトリウム水溶液の過剩を加え反応させる, 赤紫色 のカルバニオンを生成する。ついで酶酸酸性にし，水中 
ひ注入し，ベンゼン抽出を行なう。粗生成物は 45\% 収 率で得られ, ベンゼン一石油エーテルで再結晶をくりか えし精製す。m $145 \sim 148^{\circ} \mathrm{C}$ 。
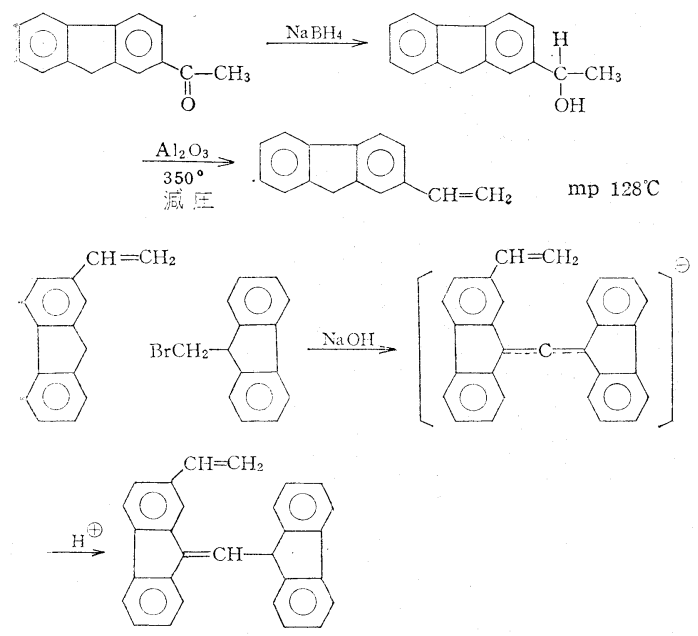

3-ビニルピレン ${ }^{60)}$ : このものは光電導性ポリマーを得 る目的で合成されている。ピレンー3-アルデヒドとトリ フェニルメチレンホスホランとの間の Wittig 反応によ 㬏比較的高収率で合成される。 $\mathrm{mp} 89.0 \sim 89.5^{\circ} \mathrm{C}$ 。

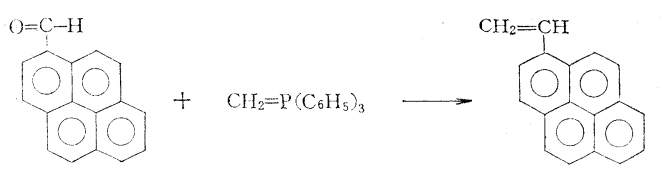

終りに本稿ををとめるに当り，別刷をお贈りいただい 孔箕浦有二, 大河原信, 鴨川慄美, 竹本喜一, 長谷川正 木, 加藤政雄, 中林宣男の諸博士にお礼申上げる。

(昭和 45 年 9 月 25 日受理)

\section{文献}

1) Y. Iwakura, F. Toda, H. Suzuki, J. Org. Chem. 32440 (1967)

2) Y. Iwakura, F. Toda, ibid. 312875 (1966)

3) J.W. Lynn, ibid. 241030 (1959)

4) 鈴木英明, 東京大学学位論文 (1968)

5) Y. Iwakura, F. Toda, Y. Torii, J. Polym. Sci. A-1 42649 (1966)

6) Y. Iwakura, F. Toda, Y. Torii, R. Sekii, $J$. Polym. Sci. A-1 62681 (1968)

7) Y. Iwakura, F. Toda, Y. Torii, R. Sekii, J. Polym. Sci. A-1 51585 (1967)

8) L.D. Taylor, T.E. Platt, J. Polym. Sci. B 7 597 (1969)

9) Y. Iwakura, F. Toda, Y.Torii, Tetrahedron 23 3363 (1967)

10) Y. Iwakura, F. Toda, Y. Torii, K. Tomioka, Tetrahedron 24575 (1968)
11) Y. Iwakura, F. Toda, Y. Torii, R. Sekii, J. Polym. Sci. A-1 62165 (1968)

12) Y. Iwakura, F. Toda, Y. Torii, J. Org. Chem. 323202 (1967)

13）鳥居芳典, 東京大学学位論文 (1968)

14) Y. Iwakura, F. Toda, Y. Torii, J. Org. Chem. 312875 (1966)

15) M. Imoto, K. Takemoto, Synthesis 1970173

16) N. Ueda, K. Kondo, M. Kono, K. Takemoto, M. Imoto, Makromol. Chem. 12013 (1968)

17) K. Kondo, H. Iwasaki, N. Ueda, K. Takemoto, M. Imoto, Makromol. Chem. 125298 (1969)

18) H. Kaye, J. Polym. Sci. B 71 (1969)

19) J. Pitha, P.O.P. Ts'o, J. Org. Chem. 331341 (1968)

20) K. Kondo,H. Iwasaki, N. Ueda, K. Takemoto, M. Imoto, Makromol. Chem. 12021 (1968)

21) C.G. Overlergen, I.C. Kogon, J. Am. Chem. Soc. 761879 (1954)

22) R.L. Frank et. al., ibid. 681365 (1946)

23). F. Cassidy, A.S. Jones, Europ. Polymer J. 2 319 (1966)

24) H. Schott, G. Greber, L. Bucsis, Makromol. Chem. 136303 (1970)

25) H. Schott, G. Greber, ibid. 136307 (1970)

26) K. Kondo, H. Iwasaki, K. Takemoto, 未発表 15) 参照

27) M.T. Doel, A.S. Jones, N. Taylor, Tetrahedron Letters 19692285

28）栗栖安彦，西山弘隆，大河原信，工化 70593 (1967)

29) T. Nakai, K. Shioya, M. Okawara, Makromol. Chem. 10895 (1967)

30) M. Kato, J. Polymer Sci. B 7605 (1969)

31) 加藤政雄, 新高分子とその忘用 (工業技術院研究 機関高分子研究成果発表会資料）p 19 (1970)

32) M. Kato, M. Hasegawa, T. Ichijo, J. Polym. Sci. B. 8263 (1970)

33) 長谷川正木, 高分子化学 27337 (1970); M. Hasegawa, Y. Suzuki, J. Polymer Sci. B 5813 (1967) ; M. Hasegawa, Y. Suzuki, F. Suzuki, H. Nakanishi, ibid. A-1 7743 (1969); M. Hasegawa, F. Suzuki, H. Nakanishi, Y. Suzuki, ibid. B 6293 (1968); F. Suzuki, Y. Suzuki, H. Nakanishi, M. Hasegawa, ibid. A-1 72319 (1969)

34) H. Kamogawa, M. Kato, H. Sugiyama, $J$. Polym. Sci. A-1 62967 (1968); 鴨川博美, 新 高分子とその応用 (工業技術院研究機関高分子研 究成果発表会資料) p 27 (1970)

35) H. Kamogawa, J. Polym. Sci. A-1 7725 (1969)

36) T. Endo, R. Numazawa, M. Okawara, Makromol. Chem. 12346 (1969)

37) T. Endo, R. Numazawa, M. Okawara, Bull. Chem. Soc. Japan 421101 (1969)

. 38) 栗栖安彦, 西山弘隆, 大河原信, 工化 711741 
(1968)

39) N. Nakabayashi, G. Wegner, H.G. Cassidy, J. Polym. Sci. A-1 6869 (1968)

40) N. Nakabayashi, G. Wegner, H.C. Cassidy, ibid. A-1 7583 (1969)

41) G. Manecke, H.J. Beyer, Makromol. Chem. 123 223 (1969)

42) Y. Iwakura, K. Uno, N. Nakabayashi, W. Chiang, J. Polym. Sci. A-1 53193 (1967)

43) Y. Iwakura, N. Nakabayashi, M.H. Lee, Makromol. Chem. 104 37 (1967)

44) Y. Iwakura, K. Uno, N. Nakabayashi, W. Chiang, Bull. Chem. Soc. Japan 42741 (1969)

45) Y. Iwakura, K. Uno, N. Nakabayashi, T. Kojima, Bull. Chem. Soc. Japan 41186 (1968)

46) O. Ariga, T. Kurosaki, M. Uchiyama, Y. Iwakura, Makromol. Chem. 99126 (1966)

47) K. Uno, Y. Iwakura, M. Makita, T. Ninomiya, J. Polym. Sci. A-1 52311 (1967); K. Uno, M. Makita, S. Ooi, Y. Iwakura, ibid. A-1 6 257 (1968)

48) Y. Iwakura, Y. Imai, K. Yagi, ibid. A-1 6 1625 (1968)

49) T.K. Dystra, D.A. Smith, Makromot. Chem.
134209 (1970)

50) Y. Iwakura, F. Toda, K. Hattori, J. Polym. Sci. A-1 61643 (1968)

51) Y. Minoura, Y. Sakanaka, ibid. A-1 73287 (1969

52) H. Hopff, M.A. Osman, Makromol. Chem. 135 175 (1970)

53) H. Yamaguchi, Y. Minoura, J. Polym. Sci. A-1 8929 (1970)

54) C.G. Overberger, P.S. Yuen, J. Am. Chem. Soc. 921667 (1970)

55) J.K. Stille, L.D. Gotter, IUPAC Intern. Symposium on Macromol. Chem. Preprints Vol 1, 131 (1969)

56) C.L. Schilling, Jr., J.E. Mulvaney, Macromole-cules 1445 (1968)

57) H. Hopff, P. Peristein, Makromol. Chem. 125 247 (1968)

58) D. Braun, E-J. Quesada Lucas, W. Neumann, ibid. 127253 (1969) p-クロルスチレンのグリ ニヤー化合物とフェニルアセタルデヒドとの反応で 合成される。融点 $160^{\circ} \mathrm{C}$

59) H.J. Förster, G. Manecke, ibid. 13353 (1970)

60) K. Tanikawa, S. Kusabayashi, H. Hirata, $H_{\text {เ }}$ Mikawa, J. Polymer Sci. B 6275 (1968)

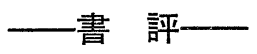

\section{酵素反応のしくみ}

最近，有機化学，高分子化学の分野の人が生化学亡関 連を持ちながら仕事を進めている報告が多くみられるよ らになってきた。著者も有機化学の分野から生化学へと 進んで行った人であり, したがってこの本は生化学の分 野の人が書いたものと違って有機化学, 高分子の分野の 人にも非常にわかりやすい。内容は 2 章からなり第 1 章 では「エステルの加水分解とアシル基の転位反応」と題 し, カルボン酸エステルの加水分解の機構, イミダゾー ル触媒によるエステルの加水分解, また核酸はりン酸エ ステル結合でつながった高分子であり，そのリン酸エス
現代化学シリーズ 46 大垣和一郎著

東京化学同人 発行, 166ページ, 720円

テル結合の生成と開裂の機構を知ることは重要なことか ら, その加水分解, 酸化的リン酸化について最近の研究 から解説している。第 2 章では「酵素の反応」と題し, 補酵素の反応, 酵素と基質の結合, 酵素反応の実例を上 げて解説している。特に補醭素の反応では代表例を上げ て有機化学的に書かれているためわかりやすい。著者も 述べているように有機化学々酵素反応の境界領域に横た わる問題点をわかりやすく解説していることに敬意を表 したい。值段も手ごろなので一読をおすすめしたい。

(遠藤剛) 